\title{
The labor market integration of refugees in the United States: Do entrepreneurs in the network help?*
}

\author{
Olivier Dagnelie ${ }^{\dagger}$ Anna Maria Mayda Jean-François Maystadt $^{\S}$
}

October 10, 2018

\begin{abstract}
We investigate whether entrepreneurs in the network of refugees - from the same country of origin - help refugees enter the labor market by hiring them. We analyze the universe of refugee cases without U.S. ties who were resettled in the United States between 2005 and 2010. We address threats to identification due to refugees sorting into specific labor markets and to strategic placement by resettlement agencies. We find that the probability that refugees are employed 90 days after arrival is positively affected by the number of business owners in their network, but negatively affected by the number of those who are employees. This suggests that network members who are entrepreneurs hire refugees, while network members working as employees compete with them, which is consistent with refugees complementing the former and
\end{abstract}

*First draft: July 2016. Anna Maria Mayda thanks the Bureau of Population, Refugee and Migration (PRM) at the U.S. State Department for providing the data on which this analysis is based. Anna Maria Mayda worked on this analysis when she was Senior Economist at the Office of the Chief Economist at the U.S. State Department. The authors also thank Daniel Ahn, Guy Lawson, Rod Ludema, Keith Maskus, Glenn Sheriff and seminar participants at presentations at PRM and Georgetown University for insightful comments. The authors would also like to thank, for useful comments, seminar participants at the 2017 European Economic Association (EEA) Meetings in Lisbon, at the 2016 9th AFD-CGD-World Bank Migration and Development Conference in Florence, at the ZEW Workshop on "Assimilation and Integration of Immigrants" in Mannheim, at the University of Richmond, at the 7th Annual OECD Conference on "Immigration in OECD Countries" in Paris, and at the USC Conference on the "Impacts of Refugees in Hosting Economies" in Los Angeles. All errors are ours.

${ }^{\dagger}$ CREM (UMR CNRS 6211), Université de Caen Normandie, France. Email: olivier.dagnelie@unicaen.fr.

$\ddagger$ Economics Department and SFS, Georgetown University. Email: amm223@georgetown.edu.

$\S$ Institute of Development Policy (IOB), University of Antwerp and Department of Economics, Lancaster University Management School. Email: j.maystadt@lancaster.ac.uk. 
substituting for the latter.

Keywords: Refugees, labor market integration, entrepreneurship .

JEL Classification: F22, J61 
"An immigrant himself, Chobani yogurt founder [Hamdi Ulukaya] becomes icon for refugees.

... Despite warnings against hiring refugees, Ulukaya has made executive decisions to of-

fer employment to people who have fled from hunger, persecution and fear." (Al Monitor,

October 5, 2015)

\section{Introduction}

Since its creation with the 1980 Refugee Act, the U.S. Refugee Admissions Program (USRAP) has resettled in the United States more than 3 million individuals fleeing persecution, war or violence in their countries of origin. One of the main goals of the program is the successful labor market integration of refugees into the local communities where they are placed. The drivers of the refugee (and immigrant in general) labor market integration are also the focus of academic interest. The existing literature shows that, among the many factors affecting the labor market assimilation of foreign-born workers, ethnic networks are especially important. Ethnic networks are broadly defined as the group of migrants from the same country of origin or community as foreign workers. In this paper we investigate whether entrepreneurs within the ethnic network help refugees' labor-market integration by hiring them. Anecdotal evidence indeed suggests a link between migrant entrepreneurs and access to the labor market by foreign workers. According to a recent piece on National Public Radio (NPR), Belgian Turks fare better on the Belgian labor market than Belgian Moroccans because they are helped (employed) by entrepreneurs in their networks (NPR 2016). A similar story made newspaper headlines lately - that the CEO of Greek-yogurt Chobani "fills" his plants with refugees. This is the channel we explore in this paper. ${ }^{1}$

We analyze the universe of refugee cases without U.S. ties who were resettled in the United States between 2005 and 2010. It is worth noting that refugees without U.S. ties do not decide where they go upon arrival to the United States. Their placement decisions are taken by resettlement agencies, as a function of individual characteristics we observe in the data and control for in the analysis. Importantly, no employee of the resettlement agencies meets the refugee before the placement decision

\footnotetext{
${ }^{1}$ Entrepreneurship is high among foreign-born workers: Kerr and Kerr (2017) finds that about 27 percent of immigrants in the U.S. were entrepreneurs in 2008 (24 percent during 1995-2008).
} 
is made. This implies that our results cannot be driven by refugees sorting into specific labor markets nor by resettlement agencies placing them according to unobserved individual characteristics. At the same time, the resettlement agencies do take into account the characteristics of the location where they might place refugees - for example, the availability of local programs and communities able to meet the refugees' needs. This might be an issue for identification since unobserved characteristics of the community of placement could be correlated with both our main regressors (the overall size of the network and the number of business owners) and the dependent variable (the labor market integration of refugees). We address these threats to identification by including a full set of fixed effects and by exploiting the practical features of the U.S. refugee resettlement program (as in Beaman, 2012). Therefore, our results are not driven by strategic placement of resettlement agencies as a function of location characteristics.

We find that, the greater the number of business owners in the refugee network, the higher the probability that the refugee is employed 90 days after arrival. At the same time, the greater the number of refugee employees within the network, the lower the probability that the refugee is employed 90 days after arrival. These results are consistent with the hypothesis that network members with their own businesses hire refugees, while network members working as employees compete with refugees. In other words, refugees "complement" network members who own businesses and "substitute" for network members who work as employees. Our findings indicate that increasing the number of business owners in the refugee network by one standard deviation increases the probability that the refugee will be employed by about 3.5 percentage points. Given that the mean level of employment in our sample is $31 \%$, this represents an increase of over $11 \%$. Similarly, increasing the number of employees in the refugee network by one standard deviation decreases the probability that the refugee will be employed by about 4.4 percentage points, which represents a decrease of over $14 \%$. To put these marginal effects into perspective, because of a greater number of business owners in the network the probability for a refugee from Vietnam - who finds on average 244 entrepreneurs in her network in the commuting zone $(\mathrm{CZ})$ of first placement - to be employed is 4 percentage points higher than for a refugee from Liberia (who finds on average only 1 entrepreneur). At the same time, the higher number of employees in the network implies that a refugee from Vietnam (who finds on 
average 1,465 employees in the network in the $\mathrm{CZ}$ of first placement) has a 10 percentage points lower probability to be employed compared to a refugee from Liberia (who finds on average only 210 employees). The results are both statistically and economically significant and are robust to using alternative specifications. We discuss and rule out alternative interpretations of our findings. An important policy implication can be derived from our results. Policymakers will be able to achieve two goals at once: by providing business incentives and opportunities to tenured refugees, they can help the latter as well as newly arrived refugees.

Our contribution is twofold. First, the existing literature shows that networks provide information on labor market conditions and opportunities to recent refugees and immigrants, as well as job referrals to firms about foreign workers (Munshi, 2003; Beaman, 2012). ${ }^{2}$ However, refugees and migrants may face discrimination in the labor market. Hence, even with additional information from network members, they may not be able to find a job. Against this background, we formulate our hypothesis that business owners in the network might help refugee labor market integration by hiring refugees. To our knowledge, this channel is new in the network and migration literature. ${ }^{3}$ There may be different reasons why business owners in the network want to hire refugees who are co-nationals. Sharing a language or business culture could enhance productivity, lowering transaction and communication costs; managers may also experience less noise in productivity signals from workers with a similar background; job-search networks may provide useful information lowering the cost of information acquisition; finally, another reason could be discrimination or preferences.

Second, very few papers in the academic literature analyze the labor market outcomes of refugees resettled within the United States, most likely due to unavailability of data. ${ }^{4}$ We are the first to

\footnotetext{
${ }^{2}$ The migration literature has analyzed other mechanisms, other than information transmission, through which networks impact newly arrived foreign-born individuals, as discussed in Dolphin and Genicot (2010), Munshi (2014a), and Munshi (2014b). One of them is the role of networks in providing credit. Networks also mitigate the impact of shocks in the countries of origin by facilitating migration flows and integration in the U.S. (Clemens, 2017; Mahajan and Yang, 2017).

${ }^{3}$ Consistent with our hypothesis, a related literature shows that migrant managers are more likely to hire workers from the same ethnic background (Åslund et al., 2014, Bandiera et al. 2009, Giuliano, et al., 2009, 2011, and Ansala et al. 2018).

${ }^{4}$ To our knowledge, the only academic papers that shed light on this topic are Cortes (2004), Beaman (2012) and Bansak et al. (2018). Cortes (2004) does not observe refugees but can identify in the U.S. Census those who
} 
directly observe and analyze a very large number of refugee cases resettled in the United States (indeed, as mentioned above, we take into account the universe of refugees without U.S. ties who arrived between 2005 and 2010). Using these data we provide the first large-scale evidence on the fraction of refugees, resettled in the United States, who find a job in the short run and on the individual-level characteristics that are correlated with finding a job. We show that almost a third of refugees (without U.S. ties) are employed 90 days after arrival. We also find that the probability that a refugee is employed after three months from arrival is positively correlated with the refugee's level of education, negatively correlated with most "support" variables - indicating whether the applicant has a government cash, medical, etc. assistance source of support - and follows an inverse U-shaped pattern over the life cycle. Controlling for the level of education, age and other individual-level controls, we also find that the greater the number of household members who accompany the refugee, the lower the probability that the refugee is employed after 90 days from arrival. ${ }^{5}$

The remainder of the paper is organized as follows. Section 2 explains how our paper fits into the existing literature. Section 3 gives information on the data and shows the summary statistics. We explain the identification strategy in Section 4 and introduce the empirical specification in Section 5. In Section 6 we present the main empirical results while in Section 7 we discuss a number of extensions and robustness tests. Finally Section 8 concludes.

\section{Literature Review}

Our contribution lies at the intersection of three strands of the literature which analyze, respectively: the impact of ethnic networks on the labor market outcomes of foreign workers, the role of migrant entrepreneurs in the economy, and the labor market integration of migrants.

Ethnic networks can play an informational role and facilitate the labor market assimilation of are most likely to be refugees within the foreign-born population, based on individual characteristics correlated with refugee status. Beaman (2012) observes refugees placed by one of the nine resettlement agencies. Bansak et al. (2018) demonstrate that current resettlement programs in Switzerland and the U.S. could be improved by leveraging synergies between refugee characteristics and resettlement sites. However, they do not consider the size and composition of networks as determinants of labor integration.

${ }^{5}$ The relationship between household size and employment is theoretically ambiguous but, in this context, a negative sign is not surprising since household size may proxy for a poor background. 
migrants and refugees. Networks provide information on the quality of potential workers through job referrals, which enables managers to attain a better match between workers and firms (Montgomery, 1991). In addition, the new hires will have an incentive not to shirk so as to avoid social sanctions from the network in case of misbehavior (Munshi, 2014b). Networks can also provide information on labor market opportunities to agents in search of a job (Calvó-Armengol and Jackson, 2004). The informational role of ethnic networks for both sides of the market has been abundantly investigated in the migration literature, for example by Munshi (2003) and Beaman (2012). ${ }^{6}$ In his seminal paper, Munshi (2003) shows that the labor market outcomes of Mexican migrants improve the greater the size of the network - from their community of origin back in Mexico - and suggests that networks help migrants by providing job referrals in a situation in which job-related information is not perfect. The estimates in the paper control for individual fixed effects and show that Mexican immigrants to the United States are more likely to be employed and earn a higher wage when the size of their network is exogenously larger. On the other hand, Borjas (2000) finds that ethnic enclaves hampers the economic assimilation of migrants due to residential segregation.

Beaman (2012) further explores the informational role of networks in a dynamic model of ethnic networks with multiple cohorts. She focuses on the labor market integration of refugees who only just arrived to the United States (90 days before). She analyzes the role in this process played respectively by "recent" refugees, who came to the United States in the preceding two years, and "tenured" refugees, who have been in the country for more than two years. She finds that an increase in the number of recent refugees worsens the labor market outcomes of newly-arrived refugees while an increase in the number of tenured refugees improves them. Beaman interprets the results as consistent with a job information story according to which tenured refugees provide information to newly-arrived refugees while recent refugees compete with them for information. Beaman is the first in the literature to take advantage of the exogenous variation in refugees without U.S. ties. Our data

\footnotetext{
${ }^{6}$ In this Section we focus on papers that analyze U.S. data. However similar results are found for other countries. Edin et al. (2003) and Damm (2009) find that migrant networks, defined as ethnic enclaves, improve the labor market outcomes of immigrants in Sweden (for the less skilled) and Denmark, respectively. The authors of both papers interpret their results as evidence of the informational role of networks. We describe other channels through which ethnic networks may impact the labor market outcomes of immigrants in footnote 1 .
} 
and identification strategy are closely related to hers but we analyze the entire universe of refugees without U.S. ties, while she looks at cases resettled by only one of the resettlement agencies. In addition, the channels of investigation are clearly different although related: contrary to the common belief that networks are usually beneficial for new arrivals, both our paper and Beaman's analysis point out that the effect of networks is highly non-linear, often positive but other times negative.

There is evidence in the literature to suggest that ethnic networks not only affect the integration of foreign workers in the labor market but also the type of job they end up in. Patel and Vella (2012) uncover strong evidence of network effects in the occupational choice of immigrants in the United States. They find that newly arrived immigrants follow their compatriots, from previous waves of immigration, and tend to find employment in the same occupations (and enjoy a wage premium), with a stronger effect for low-skilled migrants. This result is not driven by skill-based sorting, but rather by sharing information about job opportunities through networks. Similar to Patel and Vella (2012), occupational concentration of migrants by nationality is observed by Andersson et al. (2014) who find that immigrants are particularly likely to work with co-nationals and immigrants from other countries. Again, the interpretation is that ethnic networks play a role in shaping the observed occupational distribution.

Another strand of the literature emphasizes the role of migrant entrepreneurs in the economy. Occupational concentration among migrants seems particularly prevalent in self-employed activities - which are at the core of our hypothesis. Fairlie and Lofstrom (2013) document that immigrant entrepreneurship has grown steadily over the last decades. The authors show that migrant business-owners are concentrated in a few states - California, Florida, NY and Texas representing approximately $50 \%$ of the total - and sectors - Construction, Professional Services, Other Services, Retail Trade, Health Care and Social Assistance, Accommodation, Recreation and Entertainment. Kerr and Mandorff (2015) conjecture that members of small ethnic networks acquire business-specific skills through informal exchanges of information on their business activities and posit that these social interactions are complementary to production. ${ }^{7}$

\footnotetext{
${ }^{7}$ Kerr and Mandorff (2015) broadly explain how ethnic networks affect occupational specialization among ethnic groups. However, their two-sector model is applicable to a choice between self-employment and employment among migrants.
} 
Finally, our analysis touches upon the literature seeking to identify the main factors of assimilation among migrants. Several studies have stressed the importance of language skills and education for the labor market assimilation of migrants (Chiswick, 1991; Borjas, 1994; Chiswick and Miller, 1995; Cortes, 2004).

\section{Data and Summary Statistics}

We analyze refugee labor-market integration as a function of individual-level covariates, as well as aggregate variables which vary across U.S. commuting zones (CZs), years of arrival and refugees national origin. Our analysis is based on data from several sources. We use highly-confidential individual-level administrative data from the Worldwide Refugee Admissions Processing System (WRAPS) data set, housed at the Refugee Processing Center (RPC) - RPC is part of the Bureau of Population, Refugees, and Migration (PRM) at the U.S. State Department. ${ }^{8}$ WRAPS contains detailed individual-level information about the universe of refugees resettled to the United States from 1990 to the present. Given that we observe the universe of refugees, there is no sampling error in our data. For every refugee resettled to the United States we know the year of arrival, the city and state of placement as well as individual characteristics such as age, gender, marital status, level of education, number of household members in the application, country of origin and type of refugee - i.e., whether the refugee is with or without U.S. ties.

U.S. State Department is responsible for the initial placement and resettlement of refugees in the United States. In practice, U.S. State Department enters into agreements with various resettlement agencies, which provide reception and placement services for the first three months of refugees' stay. Broadly speaking, refugees resettled in the United States are of two types: refugees "with U.S. ties" and those "without U.S. ties." Refugees who report to have a U.S. tie are likely to be placed in the same geographic location as their family or friends living in the U.S.. Cases without U.S. ties are those of refugees with no family or friends in the United States. For the analysis in this paper, we restrict

\footnotetext{
${ }^{8}$ Refugee records in WRAPS are protected under Section 222(f) of the Immigration and Nationality Act, 8 U.S.C. $\S 1202(\mathrm{f})$, and may be subject to the Privacy Act of 1974, as amended, 5 U.S.C. $\S 552 \mathrm{a}$. According to Immigration and Nationality Act Section 101, refugees are defined as individuals living abroad who have a well-founded fear of persecution based on race, religion, nationality, social group status or political opinion in their home country.
} 
our attention to refugees with no U.S. ties. Importantly, together with arrival information, WRAPS also includes information on the labor-market outcomes of refugees (specifically their employment status) at 90 days after arrival. This information comes from follow-up interviews of the refugees which we can access only for refugees resettled from 2005 on. Hence, the period of our analysis is 2005-2010. Given the timing of the follow-up interviews, at 90 days after arrival, our focus is on refugees' integration in the labor market in the short run, just like in Beaman (2012).

Finally, using the WRAPS data, we can also measure each refugee's ethnic network which we define as the community of refugees without U.S. ties, arrived up to one year previously (since 1990), from the same country of origin as the refugee, living in the same CZ where the refugee is placed upon arrival and is currently observed. Using the U.S. American Community Survey (ACS), we can also construct the fraction of business owners (self-employed) and of employees for each nationality and CZ at the beginning of the period of analysis. Finally, we utilize data from the 1990 and 2000 U.S. Census to measure other characteristics of each nationality.

Figure 1: Number of refugee arrivals, by refugee type (refugees with or without U.S. ties), 2005-2010

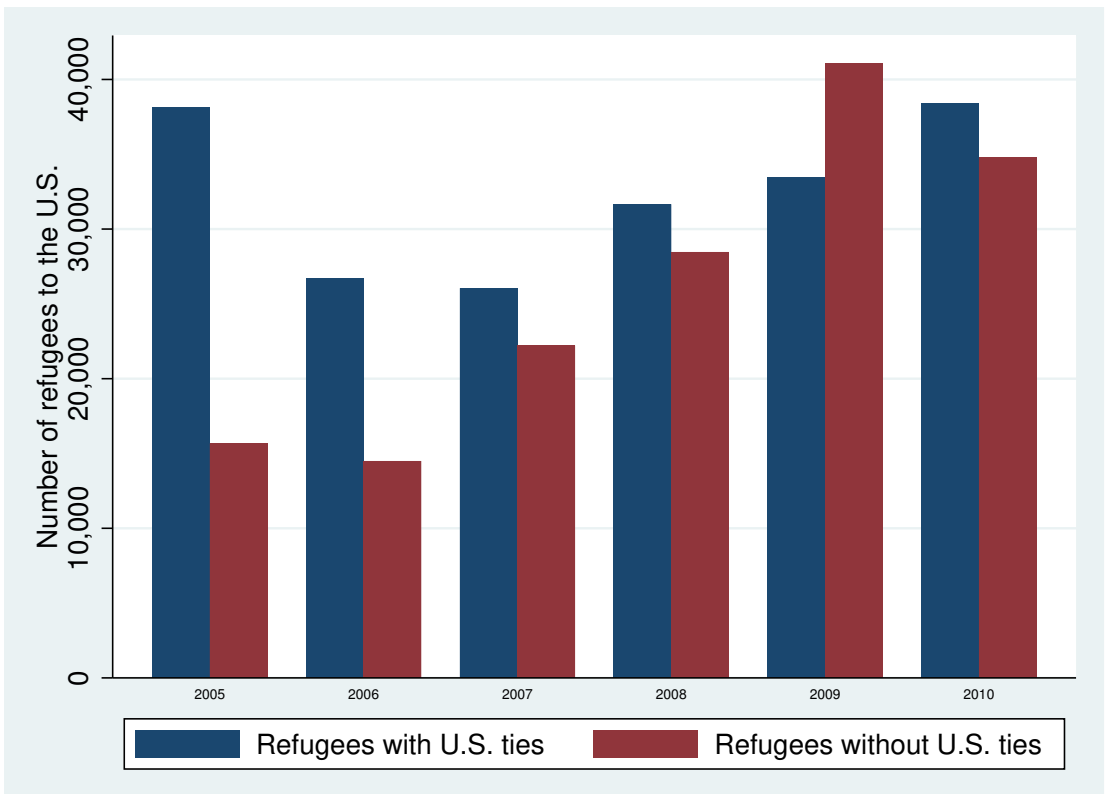

Source: WRAPS.

The U.S. welcomed about 15,000 refugees without U.S. ties in, respectively, 2005 and 2006. In later years, the number increased to around 41,000 in 2009 and 35,000 in 2010. Importantly, refugees 
without U.S. ties represent a substantial fraction of the overall number of refugees resettled to the United States (see Figure 1). In 2005, refugees without U.S. ties represented around 30 percent of total refugees but, in every other year within our period of analysis, this fraction was higher, reaching $55 \%$ in $2009 .{ }^{9}$ Figure 2 shows the size of refugee networks (without U.S. ties) in 2010 by, respectively, country of origin and U.S. state. ${ }^{10}$ These numbers are constructed by taking the sum of refugees' arrivals for each year between 1990 and 2010. The top 5 nations of origin of refugees (without U.S. ties) are, respectively, Vietnam, Burma, Somalia, Iraq and Bhutan. Interestingly, the U.S. states with the largest networks of refugees without U.S. ties in 2010 are, respectively, Texas, California, New York state, Arizona, Georgia and Florida. Finally, Figure 3 shows the geographical distribution of refugees (without U.S. ties) across CZs within the United States in 2010. ${ }^{11}$

Figure 2: Size of networks of refugees (without U.S. ties) by nationality and U.S. state, 1990-2010
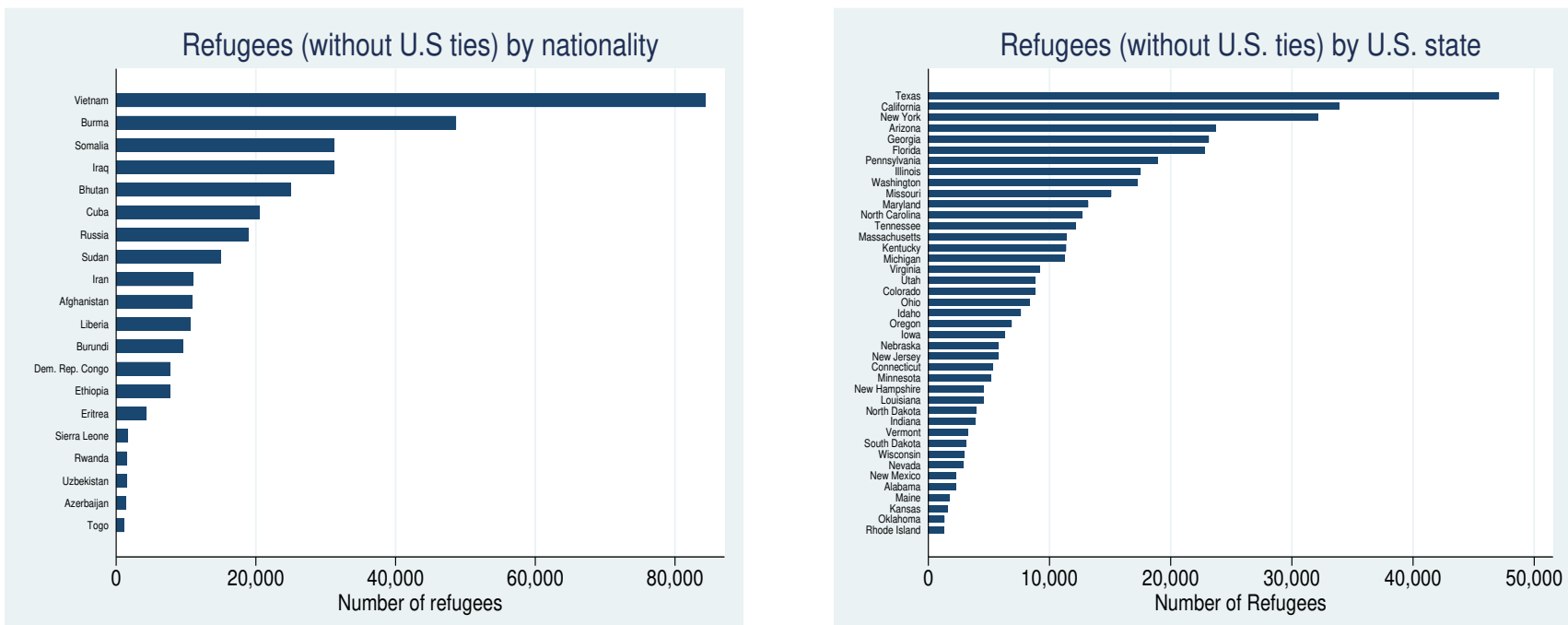

Note: Networks are constructed by summing the refugees arrivals between 1990 and 2010. For presentation purposes, only networks with size greater than 1,000 are considered. Only nationalities with more than 100 individual observations are shown.

Source: WRAPS.

\footnotetext{
${ }^{9}$ The fractions were: $29 \%$ in 2005, $35 \%$ in $2006,46 \%$ in $2007,47 \%$ in 2008, $55 \%$ in 2009 and, finally, $47 \%$ in 2010.

${ }^{10}$ From this point on, we always refer to refugees without U.S. ties, unless explicitly noted.

${ }^{11}$ Figure B.1 is equivalent to Figure 3 but is restricted to CZs for which there were arrivals in 2005-2010, i.e. CZs corresponding to the sample we analyze in the regressions.
} 
Figure 3: Size of networks of refugees (without U.S. ties) across commuting zones, 2010

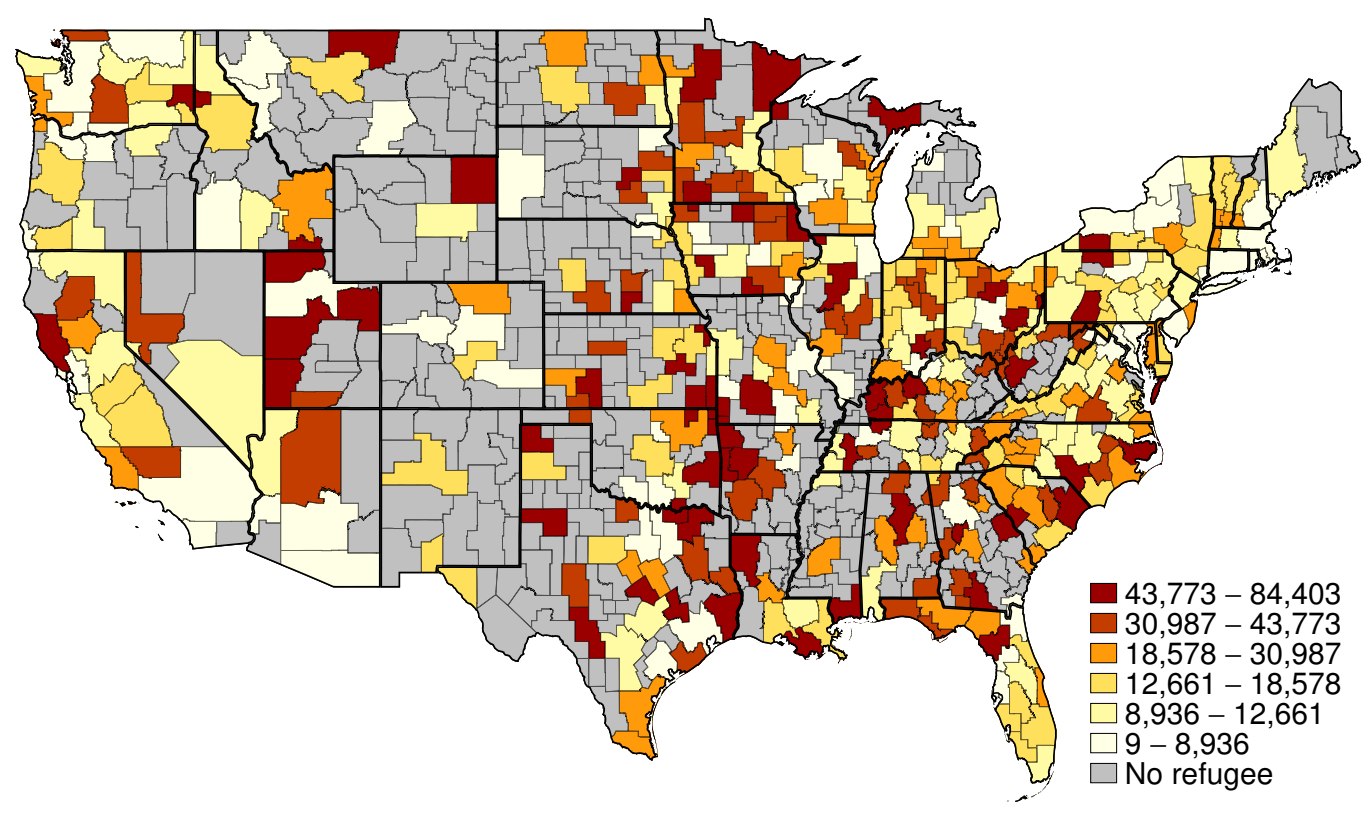

Note:The numbers are constructed by taking the sum of refugees arrivals in each year between 1990 and 2000 . Source: WRAPS.

Between 2005 and 2010, slightly less than one third of refugees without U.S. ties had a job 90 days after arrival (the precise percentage is $30.2 \%$ ). ${ }^{12}$ However, there is a substantial variation across countries of origin in the "employment rate of refugees"; we define the latter as the share of employed people among refugees without U.S. ties aged $18-64 .^{13}$ The employment rate ranges between more than $40 \%$ for Cuban refugees and less than 20\% for Afghani refugees (see left panel of Figure 4). There is also considerable variation across U.S. states (see right panel of Figure 4). Interestingly, a refugee resettled in Louisiana or Alabama has more than a 60 percent chance of finding a job after 3 months, as opposed to a probability below 10 percent in Minnesota. At first sight, there is no strong link across U.S. states between the employment rate of refugees (without U.S. ties) and the employment rate of natives (see Figure 5). For example, Louisiana and Alabama rank very low in terms of the probability that native workers are employed, while these two states rank very high in terms of the

\footnotetext{
${ }^{12}$ The percentage which appears in Table A.1 is slightly different (30.7\%) because it is based on the sample we use for the regressions.

${ }^{13}$ In other words, in the denominator of the "employment rate of refugees", we include both individuals in and out of the labor force. This is because we cannot observe whether an individual is outside of the labor force in the refugees' data. We define the employment rates in Figure 5 in a similar way.
} 
probability that refugees without U.S. ties are employed. Clearly the differences in employment rates of refugees across, respectively, U.S. states and countries of origin are the outcome of a combination of factors, such as the strength of the local labor markets, the composition of refugees in different places according to individual characteristics and nationalities, etc. The variation in our data at the individual, CZ, nationality and year levels will allow us to control for many of these factors. There is also a considerable variation in self-employment rates among migrants, both across nationalities (see left panel of Figure 6) and U.S. states (see right panel of Figure 6). Self-employment rates are high for immigrants from Burma, Iran, Vietnam and Azerbaijan, as well as for immigrants living in Georgia, Tennessee and Oklahoma.

Figure 4: Employment rates of refugees (without U.S. ties) by nationality and U.S state, 2005-2010
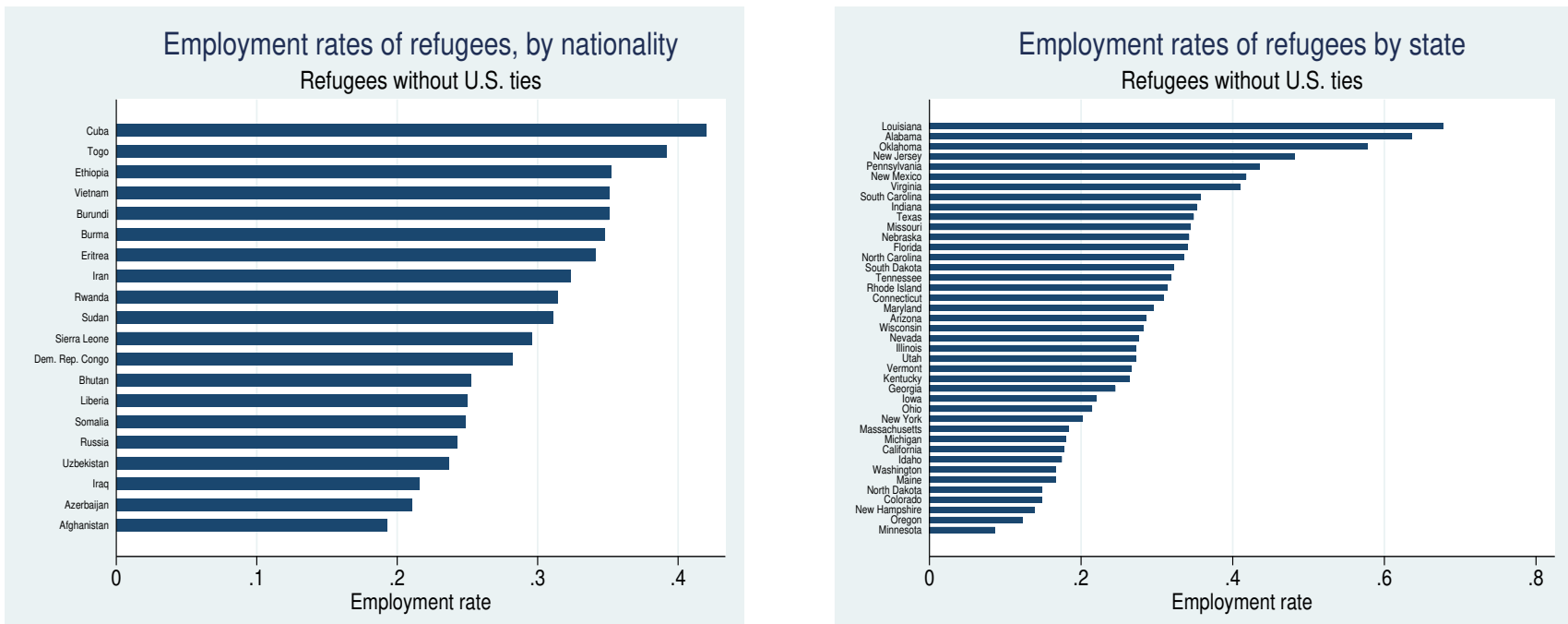

Note: Employment rates are defined as the share of employed people among refugees without U.S. ties aged between 18 and 64. For presentation purposes, only nationalities with more than 100 individual observations and a network size above 1,000 members are considered. The rates are averaged between 2005 and 2010.

Source: WRAPS. 
Figure 5: Employment rates of natives by U.S. state, 2005-2010

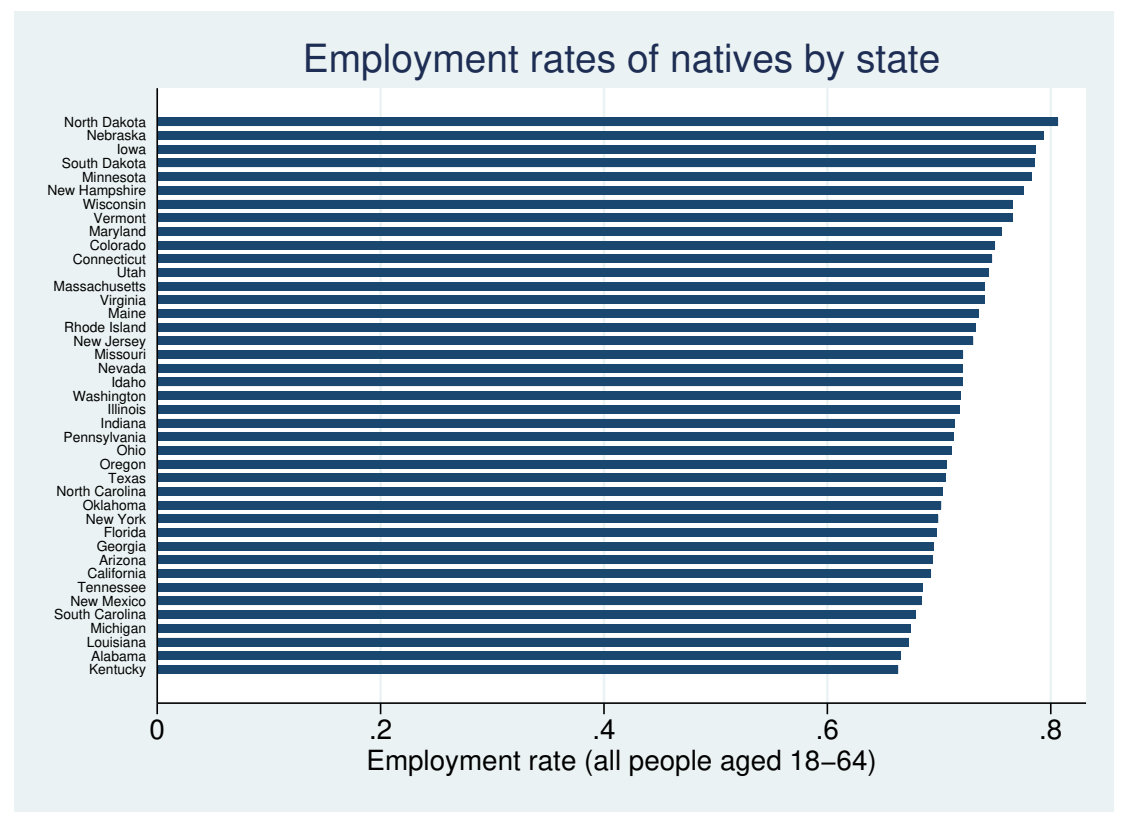

Note: Employment rates are defined as the share of employed people among individuals aged between 18 and 64 . The rates are averaged between 2005 and 2010.

Source: American Community Surveys.

Figure 6: Self-employment rates of migrants by nationality and U.S. state, 2004
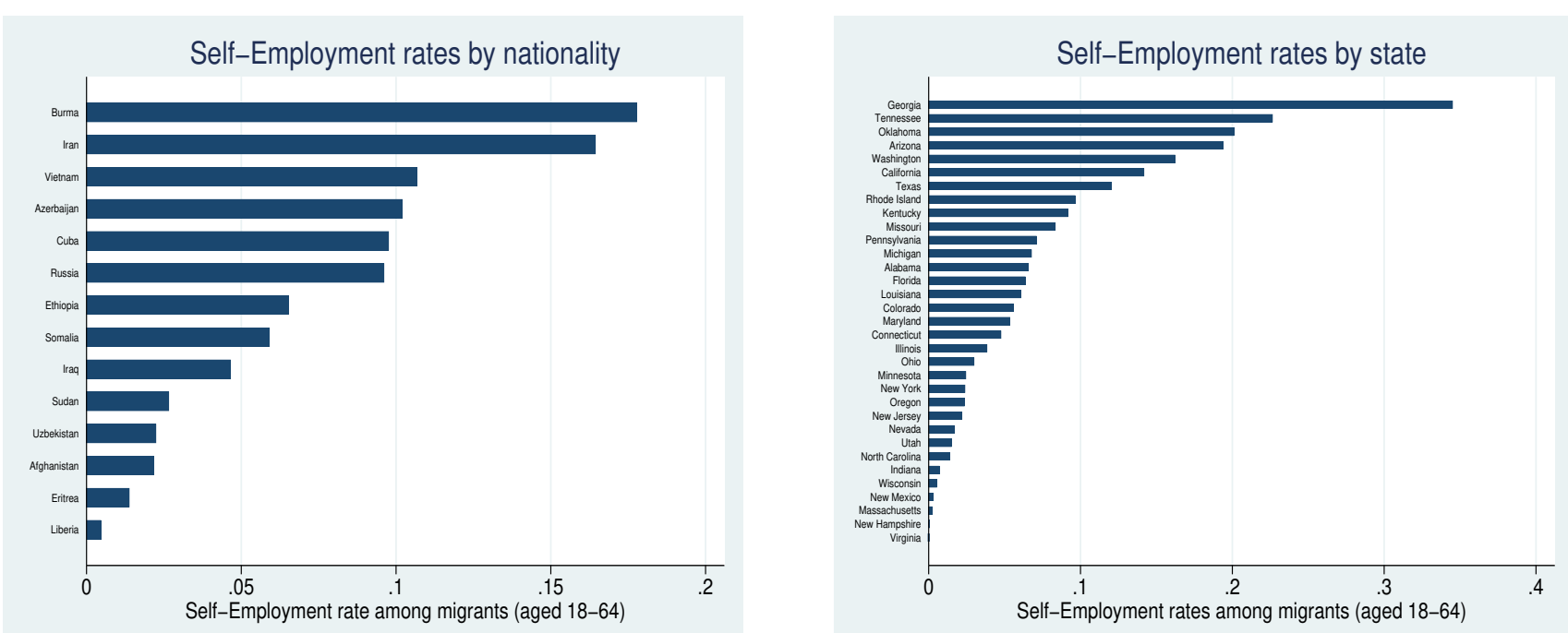

Note: Self-Employment rates are defined as the share of self-employed people among migrants aged between 18 and 64 . For presentation purposes, only nationalities with more than 100 individual observations, non-zero self-employment rates and a network size above 1,000 members are considered.

Source: American Community Survey. 
Finally, Table A.1 in the Appendix shows the summary statistics of the variables used in the empirical analysis. Refugees with no U.S ties resettled in 2005-2010 tend to be in their early 30's, have on average two family members accompanying them, are more likely to be male (with a probability of around 58\%) and to be married (with a probability of around 60\%). Almost 40 percent of refugees without U.S. ties have no formal education; around 17 percent have a primary education; 29 percent have a secondary education and approximately 7 percent went to university/college. As already mentioned above, roughly 30 percent of refugees in our sample are employed 90 days after arrival. They are placed in commuting zones where the network from the same country of origin has on average 492 members, of whom around 78 are predicted to be business owners, 298 are predicted to be employees, while the rest are either unemployed or outside of the labor force.

\section{Identification Strategy}

We take advantage of the institutional features of the U.S. Refugee Admissions Program in order to estimate the causal effect of our variables of interest. First, to assess their case for admission to the United States, all refugee applicants are interviewed overseas by an officer from the Department of Homeland Security. This makes the initial screening process of potential refugees independent from the subsequent resettlement and allocation process within the United States. The latter is administered by resettlement agencies which work with the U.S. Department of State. Aside from this, there are two main threats to identification of a causal effect which we need to address: first, individual sorting of refugees into commuting zones $(\mathrm{CZs})$ and, second, the non-random placement of refugees across CZs by resettlement agencies. In the following paragraphs we explain how we address each of these threats.

Whenever one observes the labor-market outcomes of migrants in a given locality, as a function of the number of migrants, individual sorting into CZs might be a concern. Sorting affects both the explanatory variable and the sample of individuals analyzed. First, favorable labor-market conditions in a given location may both increase the number of migrants (and migrant entrepreneurs) and improve labor-market outcomes for a given pool of newly-arrived refugees. In addition, the pool of newly-arrived refugees can be affected by individual self-selection - based on unobserved charac- 
teristics. For example, if newly-arrived refugees are free to choose where to locate, those especially driven and smart might go where there are better labor-market conditions or more opportunities to open a business. In that case, we would observe a positive correlation between the number of entrepreneurs in the network and the refugees' employment status but it would be driven by the selection of easily-employable refugees into a location with a large number of entrepreneurs. In other words, the estimates could be biased due to newly-arrived refugees sorting into specific labor markets. These issues do not arise in our empirical analysis since we analyze cases of refugees with no family members or friends already in the United States, the so called cases "without U.S. ties." Importantly, we focus on the universe of refugees without U.S. ties to construct both our dependent variable and the network variables. The placement upon arrival of refugees without U.S. ties is decided by refugee resettlement agencies, not by the refugees. ${ }^{14}$ Hence, refugee placement is exogenous with respect to their preferences.

The second threat to identification of a causal effect is the non-random placement of refugees across CZs by resettlement agencies, which could take place based on the refugees' individual characteristics and/or location characteristics. However, note that we observe all the individual characteristics of refugees known by the resettlement agencies at the time of the placement decision and can control for them in the empirical analysis. Importantly, no employee of the resettlement agencies meets the refugee before the placement decision has been made. This implies that our results cannot be driven by resettlement agencies placing refugees according to unobserved individual characteristics. At the same time, refugees without U.S. ties have to be placed close to the offices of resettlement agencies, which are likely to be located in places with non-random characteristics. In general, strategic placement by resettlement agencies may take place according to unobserved characteristics of local labor markets. A given location may have higher returns to the skills owned by foreign workers from a given country of origin. In that case resettlement agencies will likely place refugees from that country of origin in that location. For example, if the returns to the skills of Iranian workers are especially high in Los Angeles, both our regressors and the dependent variable are likely to be high as well. In our main specifications, we include CZ by nationality fixed effects, together with CZ

\footnotetext{
${ }^{14}$ Strictly speaking, refugees with U.S. ties do not chose their location either but are placed close to their relatives.
} 
by year and nationality by year fixed effects. In other words, we control for the fact that a given CZ might be a better match on average for refugees from a given country of origin, as well as for time-varying conditions of each $\mathrm{CZ}$ and of refugees of each nationality. Given the full battery of fixed effects we include in the empirical model, our estimates are only based on variation over time within a commuting-zone by country of origin pair. Hence, strategic placement by resettlement agencies can be an issue for identification only if it is time varying, i.e. if resettlement agencies are able to adjust their location decisions as a function of information which is specific for the time in which the refugee arrives to the United States. However, as pointed out by Beaman (2012), this is unlikely to be the case due to uncertainty and to delays between the time of the location decision and the time of arrival of the refugee. Describing the procedure followed by the International Rescue Committee (IRC), one of the nine resettlement agencies, Beaman (2012: 139) notes: "Overall, the IRC employee who is solely in charge of placement states that the effectiveness of strategic decision-making is limited since she never knows when a refugee who is assigned to the IRC by the State Department will actually be allowed to travel. To highlight the stochastic component, consider 2005: there were cases that were given refugee status in 2001 but who arrived in 2005 due to delays associated with heightened September 11, 2001 security requirements." Finally, the results we find suggest that time-varying strategic placement is not an issue in our analysis: If the $\mathrm{CZ}$ where the refugee is placed had higher returns to the skills owned by workers of her country of origin, at a given point in time, then we should observe a positive correlation between the probability of employment of newly arrived refugees (our dependent variable) and the number of employees in the network from the same country of origin. As shown in Section 6, instead we observe a negative correlation.

To conclude, we also worry that mobility after first placement of, respectively, newly-arrived refugees and refugees in the network, might affect our estimates. To the extent that newly-arrived refugees leave the initial location where they are placed, the pool of remaining individuals we observe to construct the dependent variable might be highly selected. We can calculate the fraction of refugees without U.S. ties who move to another location within the 3-month period. That fraction stands at a very low 7.4 percent (this fraction is very similar to what Beaman (2012) finds for refugees resettled by IRC). This is consistent with the fact that refugees should not be inclined to leave their initial 
location, given that this would imply losing the services provided by the resettlement agency. Another possibility is that mobility after first placement of tenured refugees - which constitute the network might result in a number of tenured refugees which is correlated with unobserved characteristics of the labor market. To address this issue, we exploit variation in the size of networks driven by the initial placement of refugees without U.S. ties in a given location.

Finally, if resettlement agencies were able to carry out strategic placement over time - for example as a function of the size of the communities from the same country of origin as the refugee - we should observe a positive correlation between the number of refugees without U.S. ties and the overall migrant network. As Figure 7 shows, this is not the case.

Figure 7: Migrants vs. Refugees (without U.S. ties), 2005-2010

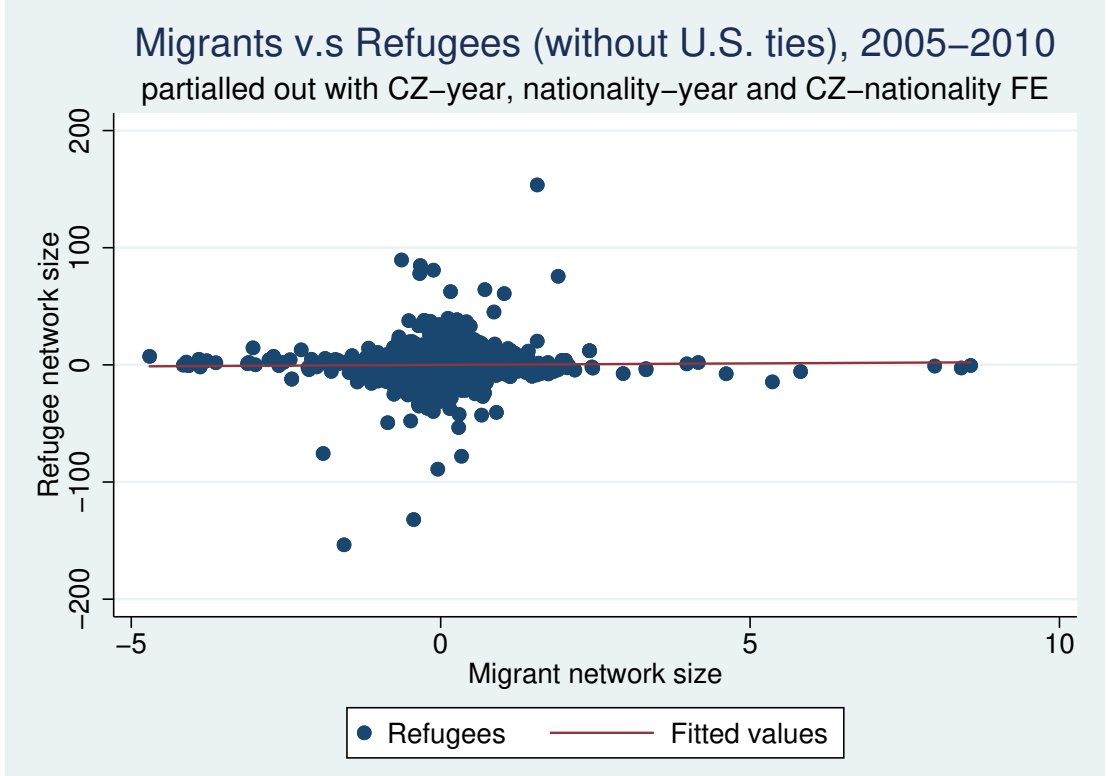

Note: Networks are constructed by summing the refugees arrivals up to the previous year between 2005 and 2010 . The network of refugees has been substracted from the network of migrants. All variables are partialled-out by commuting zone-year, nationality-year, and commuting zone-nationality fixed effects.

Source: WRAPS and American Community Surveys.

\section{Empirical Specification}

Our empirical specification is motivated by two preliminary results. First, using our data, we show that the size of the refugee's network does not have a (positive and) significant impact on the inte- 
gration of the refugee into the labor market. This result, which we discuss in Section 6, is consistent with what Beaman (2012) finds. Next, we investigate the relationship between the size of the network and our dependent variable separately, by nationality. We find evidence of heterogeneity as the relationship is positive for some countries of origin but negative for others. Among those with a positive relationship (Figure B.2), countries like Iran, Russia, Vietnam, or Sudan show a relatively high level of self-employment. Our next step is motivated both by results from the literature and anecdotal evidence which together suggest a potentially important role for entrepreneurs in the network of migrants. Indeed, Kerr and Mandorff (2015) show that entrepreneurship is high among foreign-born workers. Moreover, anecdotal evidence suggests a link between migrant entrepreneurs and access to the labor market by foreign workers. Hence, in our main specification, we explore whether the impact of the refugee network varies according to the business ownership rate in the network. Pushing this line of thinking further, we also investigate whether the impact of the network varies according to the share of employees among immigrants from the same country of origin and in the same CZ as the refugee. In other words, we assess the role of networks, in shaping refugees' labor market outcomes 90 days upon arrival, by estimating the following linear probability model:

$$
\begin{aligned}
Y_{i j k t} & =\beta_{0}+\beta_{1} \text { Network }_{j k(t-1)}+\beta_{2}\left(\text { Network }_{j k(t-1)} * \text { SelfEmployedShare }_{j k(2004)}\right) \\
& +\beta_{3}\left(\text { Network }_{j k(t-1)} * \text { EmployeeShare }_{j k(2004)}\right)+\delta^{\prime} X_{i j k t}++\gamma^{\prime} Z_{i j k t}+\alpha_{k t}+\alpha_{j t}+\alpha_{j k}+\epsilon_{i j k t}
\end{aligned}
$$

for individual $i$ from nationality group $j$ in CZ $k$ at year $t$. In our main specifications, the sample includes around 76,000 individuals, aged between 18 and 65, coming from 58 origin countries and who arrived in 120 U.S. commuting zones (CZs) between 2005 and 2010. ${ }^{15} \mathrm{CZs}$ have been recognized as the most coherent unit of analysis to investigate labor market dynamics in the United States (Autor and Dorn, 2013). ${ }^{16}$ The variable $Y_{i j k t}$ is the employment status 90 days after arrival of individual $i$

\footnotetext{
${ }^{15}$ In comparison, Beaman (2012) exploits information on 1,600 refugees resettled by IRC in 16 metropolitan areas between 2001 and 2005.

16 "Commuting Zones are clusters of U.S. counties that are characterized by strong within-cluster and weak betweencluster commuting ties." (David Dorn: http://www.ddorn.net/data.htm). We use the crosswalks provided by David Dorn to match PUMAs from the American Community Survey to 1990 CZs. Specifically, we assign individuals from PUMAs to CZs by multiplying the ACS sampling weights (corresponding to the inverse of the probability to be selected
} 
from nationality group $j$ in $\mathrm{CZ} k$ at year $t$. The main regressors of interest are the network variables. We first construct the stock of refugees (without U.S. ties) of nationality $j$ resettled in CZ $k$ up to the year before individual $i$ 's placement, $N e t w o r k_{j k(t-1)}$. We measure the stock of refugees by summing the number of refugees without U.S. ties initially placed in a given location every year since 1990 until $(t-1)$. In addition, based on the American Community Survey, we construct the share of selfemployed in the stock of migrants from the same country of origin and in the same CZ as the refugee,

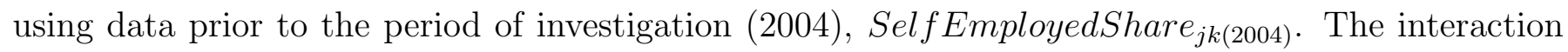
term between the refugee network and the share of self-employed in the migrant network is the first key variable of the empirical analysis. It represents the predicted number of business owners in the network of the refugee. Our hypothesis is that migrant entrepreneurs facilitate the labor market integration of refugees from the same country of origin by hiring them. In that case we would expect to estimate $\beta_{2}>0$. Similarly, we construct the share of employees in the stock of migrants from the same origin country and in the same $\mathrm{CZ}$ as the refugee, EmployeeShare ${ }_{j k(2004)} \cdot{ }^{17}$ The interaction term between the refugee network and the share of employees in the migrant network is the second key variable of the empirical analysis. It represents the predicted number, within the network of the refugee, of people working as employees. Our hypothesis is that a greater number of employees in the network makes it more difficult for newly arrived refugees from the same country of origin to find a job, due to greater competition. Hence we would expect to estimate $\beta_{3}<0$.

We augment the specification with individual characteristics known by the resettlement agency at the time of placement (age, gender, marital status, level of education, number of household members in the application). We denote this set of variables $X_{i j k t}$ in equation (1) above and Individual Controls (1) and (2) in the tables. In additional specifications, we also include individual-level information about the refugee's participation in support programs that might affect the probability of employment. We denote this set of variables $Z_{i j k t}$ in equation (1) above and Individual Controls (3) in the tables.

As mentioned above, we also include a battery of fixed effects which control for unobserved aggrein the surveyed sample) by the individual weights provided by David Dorn to map PUMAs to CZs. In addition, note that the WRAPS data set includes information on the city and state of placement which we used to determine the corresponding commuting zone.

${ }^{17}$ Moreover, in additional results, we also use the share of unemployed migrants. 
gate factors that might affect the refugee's labor market outcomes. Commuting zone by year fixed effects, $\alpha_{k t}$, capture unobserved time-varying heterogeneity at the CZ level, including productivity shocks. Nationality by year fixed effects, $\alpha_{j t}$, control for unobserved time-varying heterogeneity at the nationality level including changes in the quality of education in the origin country. Nationality by CZ fixed effects, $\alpha_{j k}$ control for the fact that resettlement agencies may place refugees from certain nationalities in specific locations where they have better labor-market outcomes on average over time. Finally, the error terms are clustered at the commuting zone and nationality levels (multi-way clustering).

\section{Results}

Table 1 presents our main results regarding the probability of a refugee being employed 90 days after arrival, as a function of the size of the network. We introduce the fixed effects sequentially, starting with a simple set of country, year and commuting zone (CZ) fixed effects in column (1) of Table 1. In regression (2) of Table 1 we augment the specification with a more comprehensive set of fixed effects: at the community zone-year, nationality-year, and commuting zone-year levels. In columns (3) and (4) we add the individual characteristics observed by the resettlement agencies at the time of the placement decision (Individual Controls (1) and (2)). Finally, we control for other individual-level variables from follow-up surveys (Individual Controls (3)) in regression (5). Across these five specifications, the coefficient of the network variable is far from being statistically different from zero. ${ }^{18}$

\footnotetext{
${ }^{18}$ We find the same result when we use the network of migrants from the same country of origin and in the same $\mathrm{CZ}$ as the refugee (see Table A.2 in Appendix). Also note that we restrict the samples of Tables 1 and A.2 to be the same as the sample of Table 2, for comparability reasons. Had we not imposed this restriction, there would be 20,000 additional individuals in Table 1. The difference between the two samples is due to unavailability of data from the ACS for some CZs. We re-estimated the regressions in Table 1 using the larger sample and obtained similar results. The coefficient of the network variable is lower in magnitude and remains insignificant.
} 
Table 1: The impact of the network

\begin{tabular}{l|ccccc}
\hline \multirow{2}{*}{ Dep. var. } & $(1)$ & $(2)$ & $(3)$ & $(4)$ & $(5)$ \\
Network (up to t-1) & \multicolumn{5}{|c}{ Employed } \\
& -0.0009 & 0.0016 & 0.0026 & 0.0029 & 0.0042 \\
& $(0.002)$ & $(0.004)$ & $(0.004)$ & $(0.005)$ & $(0.005)$ \\
\hline Observations & 75,832 & 75,645 & 75,645 & 75,645 & 73,578 \\
R-squared & 0.130 & 0.202 & 0.271 & 0.276 & 0.357 \\
\hline \hline Year, nationality, and CZ FE & $\mathrm{Y}$ & $\mathrm{N}$ & $\mathrm{N}$ & $\mathrm{N}$ & $\mathrm{N}$ \\
CZ-Year FE & $\mathrm{N}$ & $\mathrm{Y}$ & $\mathrm{Y}$ & $\mathrm{Y}$ & $\mathrm{Y}$ \\
Nationality-Year FE & $\mathrm{N}$ & $\mathrm{Y}$ & $\mathrm{Y}$ & $\mathrm{Y}$ & $\mathrm{Y}$ \\
CZ-Nationality FE & $\mathrm{N}$ & $\mathrm{Y}$ & $\mathrm{Y}$ & $\mathrm{Y}$ & $\mathrm{Y}$ \\
Ind. Controls (1) & $\mathrm{N}$ & $\mathrm{N}$ & $\mathrm{Y}$ & $\mathrm{Y}$ & $\mathrm{Y}$ \\
Ind. Controls (2) & $\mathrm{N}$ & $\mathrm{N}$ & $\mathrm{N}$ & $\mathrm{Y}$ & $\mathrm{Y}$ \\
Ind. Controls (3) & $\mathrm{N}$ & $\mathrm{N}$ & $\mathrm{N}$ & $\mathrm{N}$ & $\mathrm{Y}$ \\
\hline
\end{tabular}

Notes: Standard errors clustered at the commuting zone and nationality levels (multi-way) in parentheses. ${ }^{*},{ }^{* *},{ }^{* *}$ : significant at $10 \%, 5 \%$, and $1 \%$, respectively. All network variables are divided by 100 . The first set of individual control variables (Ind.Controls(1)) includes age of the refugee, whether she receives a matching grant source of support, and the household size. The second set of individual control variables (Ind.Controls $(2)$ ) includes education levels (primary, secondary, university, graduate, none, vocational or adult education). The third set of individual control variables (Ind.Controls(3)) includes indications of whether the refugee has received all required core services, benefits from the support of relatives or other non-governmental sources, has government cash assistance support, has a medical assistance source of support, has a source of support from Social Security, has other source(s) of support, the amount of R \& P funds spent on behalf of this family, and the amount of R \& $\mathrm{P}$ cash provided to this family.

In Appendix we show the estimates for the individual-level variables from the same regressions as in Table 1 (see Table A.3). The coefficients on age (and its square), gender, and the education levels have the expected signs. Age follows an inverse U-shaped pattern over the life cycle; male refugees are more likely to have a job (at 90 days) than female ones. Compared to the reference group with no formal education, the probability of having a job is enhanced by a higher level of education. Controlling for education, age, gender and marital status, we also find that the larger the 
number of household members who accompany the refugee, the lower the probability that the refugee is employed after 90 days from arrival. From a theoretical point of view, the relationship between the two variables could be either positive or negative. For example, a greater number of children might increase the parents' incentive to look for a job upon arrival. Yet at the same time, a greater number of kids might increase the adjustment costs shortly after arrival since parents will be busy looking for a school and might have to stay at home with their children. Also, to the extent that our individual-level controls are not able to fully capture unobserved characteristics, the sign might be driven by selection (i.e., refugees with more kids tend to come from a different socio-economiccultural background than refugees with fewer children). Interestingly, having a matching grant source of support increases the refugees job prospects. We also find that the probability that a refugee is employed three months after arrival is negatively correlated with all "support" variables - denoting for example whether the applicant has a government cash, medical, etc. source of support - with the exception of the indicator for having received all core services. We are cautious in interpreting these coefficients since these variables are likely to be endogenous, as programs target the most in need. 
Table 2: The impact of business owners and employees in the network

\begin{tabular}{|c|c|c|c|c|c|}
\hline & (1) & $(2)$ & $(3)$ & $(4)$ & $(5)$ \\
\hline Dep. var. & \multicolumn{5}{|c|}{ Employed } \\
\hline Panel A & \multicolumn{5}{|c|}{ Impact of business owners } \\
\hline \multirow[t]{2}{*}{ Network (up to t-1) } & -0.0018 & -0.0029 & -0.0035 & -0.0033 & -0.0015 \\
\hline & $(0.001)$ & $(0.003)$ & $(0.003)$ & $(0.003)$ & $(0.004)$ \\
\hline Share of self.-employed (2004) & $0.0039^{* *}$ & $0.0078^{* * *}$ & $0.0105^{* * *}$ & $0.0108^{* * *}$ & $0.0098^{* *}$ \\
\hline$\times$ Network up to $(\mathrm{t}-1)$ & $(0.002)$ & $(0.002)$ & $(0.003)$ & $(0.003)$ & $(0.005)$ \\
\hline Observations & 75,832 & 75,645 & 75,645 & 75,645 & 73,578 \\
\hline R-squared & 0.130 & 0.202 & 0.271 & 0.276 & 0.357 \\
\hline Panel B & \multicolumn{5}{|c|}{ Impact of business owners and employees } \\
\hline \multirow[t]{2}{*}{ Network (up to t-1) } & -0.0021 & -0.0010 & -0.0011 & -0.0009 & 0.0008 \\
\hline & $(0.002)$ & $(0.005)$ & $(0.005)$ & $(0.005)$ & $(0.005)$ \\
\hline Share of self.-employed (2004) & 0.0035 & $0.0125^{* * *}$ & $0.0162^{* * *}$ & $0.0166^{* * *}$ & $0.0153^{* * *}$ \\
\hline$\times$ Network up to $(\mathrm{t}-1)$ & $(0.003)$ & $(0.001)$ & $(0.001)$ & $(0.003)$ & $(0.005)$ \\
\hline Share of employees (2004) & 0.0007 & $-0.0065^{*}$ & $-0.0079^{* *}$ & $-0.0081^{* *}$ & $-0.0077^{*}$ \\
\hline$\times$ Network up to $(\mathrm{t}-1)$ & $(0.003)$ & $(0.003)$ & $(0.004)$ & $(0.004)$ & $(0.004)$ \\
\hline Observations & 75,832 & 75,645 & 75,645 & 75,645 & 73,578 \\
\hline R-squared & 0.130 & 0.202 & 0.271 & 0.276 & 0.357 \\
\hline Year, nationality, and CZ FE & $\mathrm{Y}$ & $\mathrm{N}$ & $\mathrm{N}$ & $\mathrm{N}$ & $\mathrm{N}$ \\
\hline CZ-Year FE & $\mathrm{N}$ & $\mathrm{Y}$ & $\mathrm{Y}$ & $\mathrm{Y}$ & $\mathrm{Y}$ \\
\hline Nationality-Year FE & $\mathrm{N}$ & $\mathrm{Y}$ & $\mathrm{Y}$ & $\mathrm{Y}$ & $\mathrm{Y}$ \\
\hline CZ-Nationality FE & $\mathrm{N}$ & $\mathrm{Y}$ & $\mathrm{Y}$ & $\mathrm{Y}$ & $\mathrm{Y}$ \\
\hline Ind. Controls (1) & $\mathrm{N}$ & $\mathrm{N}$ & $\mathrm{Y}$ & $\mathrm{Y}$ & $\mathrm{Y}$ \\
\hline Ind. Controls (2) & $\mathrm{N}$ & $\mathrm{N}$ & $\mathrm{N}$ & $\mathrm{Y}$ & $\mathrm{Y}$ \\
\hline Ind. Controls (3) & $\mathrm{N}$ & $\mathrm{N}$ & $\mathrm{N}$ & $\mathrm{N}$ & $\mathrm{Y}$ \\
\hline
\end{tabular}

Notes: Standard errors clustered at the commuting zone and nationality levels (multi-way) in parentheses. ${ }^{*},{ }^{* *},{ }^{* *}$ : significant at $10 \%, 5 \%$, and $1 \%$, respectively. Control variables are described below Table 1.

In Table 2 we estimate equation (1) and follow the same format as Table 1 by progressively introducing the set of fixed effects and the control variables. Table 2 shows evidence of heterogeneity 
in the impact of networks consistent with our hypothesis. In Panel A we introduce the size of the network, both linearly and in interaction with the 2004 share of entrepreneurs, into the migrant network. Note that the linear effect of the time-invariant entrepreneurship rate is absorbed by the nationality by CZ fixed effects. While the direct effect of the network is insignificant, the interaction term has a positive and significant impact. Hence the probability that the refugee is employed 90 days after arrival is positively affected by the number of business owners in the network. In columns (3), (4) and (5), where we add the individual controls such as level of education or participation in support programs, the results are very similar. Broadly speaking, results in Panel A, Table 2 are consistent with a framework in which newly-arrived refugees and migrant entrepreneurs complement each other. While our evidence is not direct, since we do not observe the hiring decisions of migrant entrepreneurs, one interpretation of our findings is that network members who are entrepreneurs hire refugees. Note that it is very unlikely that refugees who have just arrived are business owners themselves, for the following reasons: first, we observe refugees only 90 days after arrival, which is insufficient time for opening a business; second, Beaman (2012) documents that the average wage of refugees 90 days after arrival is consistent with minimum wage occupations. Hence, it is most likely our results do not capture the fact that refugees of a certain nationality (both newcomers and other refugees) have it easier when it comes to open a business in a given $\mathrm{CZ}$ at a certain point in time. In addition, we can also rule out the interpretation that newcomers learn the skills to set up a business in areas and times where co-nationals have higher entrepreneurship rates.

In Panel B, Table 2, we add the interaction of the network variable with the 2004 share of employees to the migrant network. We find that the impact is negative (and significant when we control for the individual-level variables). This means that the probability that the refugee is employed is negatively affected by the number of network members who are employees. This result is consistent with a framework in which newly-arrived refugees and network members working as employees compete with each other in the labor market. Indeed, workers from the same country of origin are likely to be highly substitutable since they might have similar skills. Given that they look for similar jobs, they penalize one another in the labor market. In particular, if tenured refugees fill some job positions, these are not available for newly arrived refugees. ${ }^{19}$

\footnotetext{
${ }^{19}$ Our results are robust to alternative types of clustering of standard errors, specifically by commuting zone and
} 
Based on the coefficient estimates in regression (4), Panel B, Table 2, our findings indicate that increasing the number of business owners in the refugee's network by one standard deviation raises the probability that the refugee will be employed by about 3.5 percentage points. Given that the mean level of employment in our sample is $31 \%$, this represents an increase of over 11\%. Similarly, increasing the number of employees in the refugee's network by one standard deviation decreases the probability that the refugee is employed by about 4.4 percentage points, which represents a decrease of over $14 \%{ }^{20}$ To put these marginal effects into perspective, because of a greater number of business owners in the network the probability for a refugee from Vietnam - who finds on average 244 entrepreneurs in her network in the commuting zone $(\mathrm{CZ})$ of first placement - to be employed is 4 percentage points higher than for a refugee from Liberia (who finds on average only 1 entrepreneur). At the same time, the higher number of employees in the network implies that a refugee from Vietnam (who finds on average 1,465 employees in the network in the $\mathrm{CZ}$ of first placement) has a 10 percentage points lower probability to be employed compared to a refugee from Liberia (who finds on average only 210 employees).

\section{$7 \quad$ Extensions and robustness tests}

In this section we extend the model and test the robustness of the results in our preferred specifications (columns (3), (4), and (5) of Table 2, Panel B). In Table 3, Panel A, we extend the empirical model by accounting for the number of unemployed members in the network of the refugee. In particular, we add the predicted number of unemployed in the network. Consistent with our interpretation of year (multi-way) or at the commuting zone level. In the former case, we use the wild cluster bootstrap sampling method, specifically the extension by Webb (2013) as suggested by Cameron and Miller (2014: 345): This extension is the preferred option when one dimension (in our case the year) has a number of clusters below 10. Table A.4 shows that the results are robust to this alternative type of multi-way clustering. Finally, using the same set of fixed effects as in column (1) of Table 2 - which reduces the severity of the incidental parameter problem - we find that the linear-probability-model and the logit model give similar results (results available upon request).

${ }^{20}$ We can compare these estimates to those in Beaman (2012) who finds that a one standard deviation increase in (t-1) network size decreases the probability of employment by 7\%. Beaman (2012) also notes that the magnitude of her effects (hence of our effects as well) is economically significant since it is larger than the refugee returns to one additional year of experience - she analyzes data from the Office of Refugees Resettlement and finds that one additional year spent in the U.S. is associated with an increase in the employment rate of refugees by $3.4 \%$. 
the results based on labor-market complementarity and substitutability, we find that the greater the number of unemployed, the lower the probability that the newly-arrived refugee gets hired. Workers from the same country of origin are likely to have similar skills and, to the extent they are actively looking for a job or already employed, they penalize one another in the labor market.

In Table 3, Panel B, we extend the empirical model by controlling for the direct effect of the overall migrant network. In Section 4, we argued that it is very unlikely that resettlement agencies are able to carry out strategic placement with respect to time-varying variables. But in the remote possibility they do, we would like to make sure our results are robust. Resettlement agencies may try to place refugees in locations with a large community of migrants from the same country of origin - the latter, in turn, may be following economic opportunities. To the extent resettlement agencies can predict the size of the migrant community at the time of arrival of refugees, our estimates could be biased. However, when we control for the overall migrant network at time (t-1), our results do not change. Admittedly, the overall migrant network at $(t-1)$ is highly endogenous, therefore these results are only suggestive. ${ }^{21}$

Next, we use the overall migrant network to measure the predicted number of business owners. In other words, we introduce both the direct effect of the overall migrant network and its interaction with the share of, respectively, self-employed and employees in the network. This way we can explore whether the number of migrant business owners from the same country of origin as the refugee whether these business owners are refugees with or without U.S. ties or economic migrants - has the same positive effect on the labor market integration of newly arrived refugees. Importantly, we instrument for the overall migrant network - both in the direct and in the interaction term - using the number of refugees without U.S. ties. We find that the impact of business owners from the same

\footnotetext{
${ }^{21}$ As shown in Panel A of Table A.6, we obtain similar results if we control for the overall migrant network at time (t-3). We also find similar results when we restrict the network to refugees arriving up to two years before the newcomer's arrival, instead of up to the previous year (Panel B, Table A.6). Our results are also robust to constructing the share of self-employed and the share of employees using data at $t-1$ (Table A.7). Similarly, they are robust to constructing the network variables as a share of the commuting zone population at $t-1$ (Table A.8). However, these results should be interpreted with caution due to potential endogeneity of the new variables. We may also be concerned that displacement of natives might take place as a result of refugees' placement. However, refugees' networks do not seem to give rise to native displacement (Table A.9 in Appendix).
} 
country of origin as the refugee is still positive and significant (see Table 3, Panel C). The first-stage coefficient, represented graphically in Figure B.3, is positive and significant. ${ }^{22}$

Another legitimate concern is the risk of confounding the heterogeneous effect coming from more entrepreneurial nationality groups with the effect linked to other intrinsic group characteristics. We construct a measure of alternative dimensions of heterogeneity across nationalities - other than entrepreneurship. Specifically, we focus on nationality-specific in-marriage rates, which capture the extent of group cohesiveness within each network and have also been found to be correlated with the entrepreneurship rate of the group. ${ }^{23}$ Kerr and Mandorff (2015) indeed show how social interactions lead to occupational stratification along ethnic lines. They conjecture that members of small ethnic networks develop business specific skills through informal exchanges of information on their business activities and posit that these social interactions are complementary to production. Panels A and B of Table 4 control for the interaction term between the network and the in-marriage rate, defined in 1990 and in 2000, respectively. The number of self-employed in the network still has a positive and significant impact on the probability of being employed.

\footnotetext{
${ }^{22}$ There are two caveats in the IV results. First, the first-stage regressions appear to be weak in Panel C of Table
} 3. The large number of endogenous variables makes the first-stage specification less efficient. A strong first-stage regression is found when we only instrument for the migration network and its interaction with the predicted number of entrepreneurs (Panel A of Table A.5). Second, the interpretation of the 2SLS results is not straightforward. Note the difference between Figure 7 and Figure B.3. In Figure 7, we relate the number of refugees without U.S. ties to the number of all the other co-ethnics (i.e. excluding refugees without U.S. ties). Instead in Figure B.3, we relate the number of refugees without U.S. ties to the overall network of all coethnics (including refugees without U.S. ties). Therefore, given the zero relationship in Figure 7 and the positive and significant correlation in Figure B.3, the firststage coefficient of the IV estimation is due to a mechanical relationship, i.e. it appears to be driven by the fact that the overall network of all co-ethnics includes refugees without U.S. ties. In light of this, it is difficult to know whether the difference between the OLS vs. IV estimates is only due to endogeneity of the OLS estimates or whether it is also driven by the fact that the IV estimates represent a Local Treatment Effect.

${ }^{23}$ We compute in-marriage rates - within group marriage rates - by refugee nationality following the methodology put forward by Kerr and Mandorff (2015). We use the US censuses from 1990 and 2000 restricted to married couples in which males migrated to the US between the age of 1 and 15. The latter is meant to avoid counting in someone who married before migrating and hence, confounding late migration with high in-marriage rates. We further restrict the sample to couples in which the husband is aged between 18 and 65 . The in-marriage rate for nationality $i$ is the ratio of the number of in-marriages for males of nationality $i$ and the total number of marriages involving males of nationality $i$. 
Table 3: Extensions

\begin{tabular}{|c|c|c|c|}
\hline & (1) & $(2)$ & $(3)$ \\
\hline Dep. var. & \multicolumn{3}{|c|}{ Employed } \\
\hline Panel A & \multicolumn{3}{|c|}{ With the share of unemployed members } \\
\hline Share of self. employ. (2004) & $0.0092^{* * *}$ & $0.0095^{* *}$ & $0.0085^{*}$ \\
\hline$\times$ Network up to $(\mathrm{t}-1)$ & $(0.003)$ & $(0.004)$ & $(0.005)$ \\
\hline Share of unemployed and employees(2004) & $-0.0008^{*}$ & -0.0007 & $-0.0007^{*}$ \\
\hline$\times$ Network (up to t-1) & $(0.000)$ & $(0.001)$ & $(0.000)$ \\
\hline Observations & 75,645 & 75,645 & 73,578 \\
\hline R-squared & 0.271 & 0.276 & 0.357 \\
\hline Panel B & \multicolumn{3}{|c|}{ Controlling for migration networks (up to t-1) } \\
\hline Share of self. employ. (2004) & $0.0162^{* * *}$ & $0.0166^{* * *}$ & $0.0153^{* * *}$ \\
\hline$\times$ Network up to $(\mathrm{t}-1)$ & $(0.001)$ & $(0.003)$ & $(0.005)$ \\
\hline Share of employees (2004) & $-0.0079^{* *}$ & $-0.0081^{* *}$ & $-0.0077^{*}$ \\
\hline$\times$ Network (up to t-1) & $(0.004)$ & $(0.004)$ & $(0.004)$ \\
\hline \multirow[t]{2}{*}{ Migration (t-1) } & -0.0000 & -0.0000 & -0.0001 \\
\hline & $(0.000)$ & $(0.000)$ & $(0.000)$ \\
\hline Observations & 75,645 & 75,645 & 73,578 \\
\hline R-squared & 0.271 & 0.276 & 0.357 \\
\hline CZ-Year, Nationality-Year \& CZ-Nationality FE & $\mathrm{Y}$ & $\mathrm{Y}$ & $\mathrm{Y}$ \\
\hline Ind. Controls (1) & $\mathrm{Y}$ & Y & Y \\
\hline Ind. Controls (2) & $\mathrm{N}$ & $\mathrm{Y}$ & $\mathrm{Y}$ \\
\hline Ind. Controls (3) & $\mathrm{N}$ & $\mathrm{N}$ & $\mathrm{Y}$ \\
\hline
\end{tabular}

Notes: Standard errors clustered at the commuting zone and nationality level in parentheses. ${ }^{*},{ }^{* *},{ }^{* * *}$ : significant at $10 \%, 5 \%$, and $1 \%$, respectively. All network variables are divided by 100 . The Network (up to t-1) variable is included and remains insignificant in all regressions. The three sets of individual control variables are described under Table 1. 
Table 3 (Continued): Extensions

\begin{tabular}{l|ccc}
\hline & $(1)$ & $(2)$ & $(3)$ \\
Dep. var. & \multicolumn{3}{|c}{ Employed } \\
\hline Panel C & Considering the network of migrants (2SLS) \\
Share of self-employed (2004) & $0.0563^{* * *}$ & $0.0579^{* * *}$ & $0.0558^{* * *}$ \\
$\times$ Migration up to (t-1) & $(0.002)$ & $(0.007)$ & $(0.014)$ \\
Share of employees (2004) & $-0.0306^{* * *}$ & $-0.0309^{* * *}$ & $-0.0287^{* *}$ \\
$\times$ Migration up to (t-1) & $(0.008)$ & $(0.008)$ & $(0.012)$ \\
Observations & 75,645 & 75,645 & 73,578 \\
R-squared & 0.248 & 0.253 & 0.339 \\
Kleibergen-Paap rk Wald F & 8.383 & 8.369 & 4.985 \\
\hline \hline CZ-Year, Nationality-Year \& CZ-Nationality FE & $\mathrm{Y}$ & $\mathrm{Y}$ & $\mathrm{Y}$ \\
Ind. Controls (1) & $\mathrm{Y}$ & $\mathrm{Y}$ & $\mathrm{Y}$ \\
Ind. Controls (2) & $\mathrm{N}$ & $\mathrm{Y}$ & $\mathrm{Y}$ \\
Ind. Controls (3) & $\mathrm{N}$ & $\mathrm{N}$ & $\mathrm{Y}$ \\
\hline
\end{tabular}

Notes: Standard errors clustered at the commuting zone and nationality level in parentheses. ${ }^{*},{ }^{* *},{ }^{* * *}$ : significant at $10 \%, 5 \%$, and $1 \%$, respectively. All network variables are divided by 100 . The MigrationNetwork (up to t-1) and the Network (up to t-3) variables are included in Panels C and D, respectively and remain insignificant in both panels. The three sets of individual control variables are described under Table 1. 
Table 4: Robustness

\begin{tabular}{l|ccc}
\hline & $(1)$ & $(2)$ & $(3)$ \\
Dep. var. & \multicolumn{3}{|c}{ Employed } \\
\hline Panel A & Controlling for social isolation $(1990)$ \\
Share of self-employed (2004) & $0.0162^{* * *}$ & $0.0165^{* * *}$ & $0.0154^{* * *}$ \\
$\times$ Network up to (t-1) & $(0.005)$ & $(0.005)$ & $(0.005)$ \\
Share of employees (2004) & $-0.0102^{* *}$ & $-0.0103^{* *}$ & $-0.0099^{*}$ \\
$\times$ Network up to (t-1) & $(0.004)$ & $(0.004)$ & $(0.005)$ \\
In-Marriage rate (1990) & -0.0004 & -0.0004 & -0.0005 \\
$\times$ Network up to (t-1) & $(0.001)$ & $(0.001)$ & $(0.001)$ \\
Observations & 62,929 & 62,929 & 61,026 \\
R-squared & 0.276 & 0.280 & 0.359 \\
\hline Panel B & Controlling for social isolation $(2000)$ \\
Share of self-employed (2004) & $0.0165^{* * *}$ & $0.0168^{* * *}$ & $0.0161^{* * *}$ \\
$\times$ Network up to (t-1) & $(0.003)$ & $(0.004)$ & $(0.005)$ \\
Share of employees (2004) & $-0.0101^{* *}$ & $-0.0100^{* *}$ & $-0.0093^{* *}$ \\
$\times$ Network up to (t-1) & $(0.004)$ & $(0.004)$ & $(0.004)$ \\
In-Marriage rate (2000) & -0.0001 & -0.0001 & -0.0001 \\
$\times$ Network up to (t-1) & $(0.000)$ & $(0.000)$ & $(0.000)$ \\
Observations & 63,157 & 63,157 & 61,145 \\
R-squared & 0.270 & 0.274 & 0.357 \\
\hline \hline CZ-Year, Nationality-Year \& CZ-Nationality FE & $\mathrm{Y}$ & $\mathrm{Y}$ & $\mathrm{Y}$ \\
Ind. Controls (1) & $\mathrm{Y}$ & $\mathrm{Y}$ & $\mathrm{Y}$ \\
Ind. Controls (2) & $\mathrm{N}$ & $\mathrm{Y}$ & $\mathrm{Y}$ \\
Ind. Controls (3) & \multicolumn{3}{|c}{$\mathrm{Y}$} \\
\hline
\end{tabular}

Notes: Standard errors clustered at the commuting zone and nationality level in parentheses. ${ }^{*},{ }^{* *},{ }^{* * *}$ : significant at 10\%, 5\%, and 1\%, respectively. All network variables are divided by 100 . The Network variable is included and remains insignificant in all regressions. The three sets of individual control variables are described below Table 1. 
Finally, the results may be sensitive to the construction of the main variables. Our definition of networks based on common nationality may be too restrictive. We construct alternative measures of the network of refugees by including in the same network all refugees with similar language or religion as the newly-arrived refugee. Specifically, we construct Linguistic Networks and Religious Networks which are based, respectively, on the bilateral linguistic or religious proximity between the refugee's country of origin and all the other nationalities present at the CZ level. We further describe the construction of these alternative networks in Appendix C. Panels A and B of Table 5 show that our results are similar when we use these alternative measures of networks. ${ }^{24}$ Finally, one may be concerned that our results are driven by nationalities associated with tiny networks. In Panel C, we show that our estimates are robust to dropping observations corresponding to small networks (network below 1000 individuals).

\footnotetext{
${ }^{24}$ Controlling for the composition of networks of other nationalities does not alter our main conclusions (Table A.10).
} 
Table 5: Robustness (cont.)

\begin{tabular}{|c|c|c|c|}
\hline & (1) & $(2)$ & $(3)$ \\
\hline Dep. var. & \multicolumn{3}{|c|}{ Employed } \\
\hline Panel A & \multicolumn{3}{|c|}{ Alternative Networks (linguistic) } \\
\hline Share of self. employ. among Linguistic network & $0.0178^{* * *}$ & $0.0182^{* * *}$ & $0.0169^{* * *}$ \\
\hline$\times$ Linguistic Network up t-1 & $(0.001)$ & $(0.003)$ & $(0.005)$ \\
\hline Share of employ. among Linguistic network & $-0.0082^{*}$ & $-0.0084^{*}$ & $-0.0080^{*}$ \\
\hline$\times$ Linguistic Network up to $(\mathrm{t}-1)$ & $(0.004)$ & $(0.004)$ & $(0.004)$ \\
\hline Observations & 75,645 & 75,645 & 73,578 \\
\hline R-squared & 0.271 & 0.276 & 0.357 \\
\hline Panel B & \multicolumn{3}{|c|}{ Alternative Networks (religious) } \\
\hline Share of self-employed among Religious network & $0.0167^{* * *}$ & $0.0171^{* * *}$ & $0.0143^{* * *}$ \\
\hline$\times$ Religious Network up to t-1 & $(0.002)$ & $(0.003)$ & $(0.005)$ \\
\hline Share of employees among Religious network & $-0.0083^{* *}$ & $-0.0083^{* *}$ & $-0.0067^{*}$ \\
\hline$\times$ Religious Network up to $(\mathrm{t}-1)$ & $(0.003)$ & $(0.004)$ & $(0.004)$ \\
\hline Observations & 75,645 & 75,645 & 73,578 \\
\hline R-squared & 0.271 & 0.276 & 0.357 \\
\hline Panel C & \multicolumn{3}{|c|}{ Dropping small networks } \\
\hline Share of self-employed (2004) & $0.0162^{* * *}$ & $0.0166^{* * *}$ & $0.0152^{* * *}$ \\
\hline$\times$ Network up to $(\mathrm{t}-1)$ & $(0.001)$ & $(0.003)$ & $(0.005)$ \\
\hline Share of employees (2004) & $-0.0079^{* *}$ & $-0.0080^{* *}$ & $-0.0076^{*}$ \\
\hline$\times$ Network up to $(\mathrm{t}-1)$ & $(0.004)$ & $(0.004)$ & $(0.004)$ \\
\hline Observations & 74,293 & 74,293 & 72,230 \\
\hline R-squared & 0.270 & 0.274 & 0.356 \\
\hline CZ-Year, Nationality-Year \& CZ-Nationality FE & $\mathrm{Y}$ & $\mathrm{Y}$ & $\mathrm{Y}$ \\
\hline Ind. Controls (1) & $\mathrm{Y}$ & $\mathrm{Y}$ & $\mathrm{Y}$ \\
\hline Ind. Controls (2) & $\mathrm{N}$ & $\mathrm{Y}$ & $\mathrm{Y}$ \\
\hline Ind. Controls (3) & $\mathrm{N}$ & $\mathrm{N}$ & $\mathrm{Y}$ \\
\hline
\end{tabular}

Notes: Standard errors clustered at the commuting zone and nationality levels in parentheses. ${ }^{*},{ }^{* *},{ }^{* * *}$ : significant at $10 \%, 5 \%$, and 1\%, respectively. All network variables are divided by 100 . The Network (up to t-1) variable is included and remains insignificant in all regressions. The three sets of individual control variables are described below Table 1. 


\section{Conclusions}

The successful labor-market integration of refugees and immigrants matters well beyond the labor market. Recently Verwimp (2015) provides anecdotal evidence that bad labor-market outcomes of refugees and migrants may contribute to their political radicalization. ${ }^{25}$ Similarly, the NPR (2016) piece mentioned in the Introduction suggests that one reason why Belgian Turks are less likely to be radicalized than Belgian Moroccans is that the former end up faring better in the labor market. ${ }^{26}$ The literature on migration and crime also points out the importance of labor market integration. The link between the two variables has been found to be weak or, in many cases, non-existent (Bell and Machin, 2013). However, when asylum seekers are found to increase crimes, such an impact seems to be mostly explained by barriers to labor market integration (Butcher and Piehl, 1998; Bell et al., 2013; Spenkuch, 2014). Couttenier et al. (2016) even show that offering labor market access to asylum seekers eliminates the impact of asylum seekers on violent crimes. Similarly, Mastrobuoni and Pinotti (2015) and Freedman et al. (2018) find that, when labor market opportunities for migrants improve once they are granted legal status, the risk of crime recidivism decreases.

In this paper we posit that network members, who are entrepreneurs, help refugees from the same country of origin by hiring them. On the other hand, network members who are employees are likely to compete with newly-arrived refugees in the labor market. Our estimates are consistent with these hypotheses. They show that increasing the number of business owners in the refugees network by one standard deviation raises the probability that the refugee will be employed by about 3.5 percentage points. Similarly, increasing the number of employees in the refugee network by one standard deviation

\footnotetext{
${ }^{25}$ Verwimp (2015) shows that the number of migrants - both first- and second-generation ones - who leave European countries to become foreign fighters in Syria and Iraq (per million inhabitants) is positively associated with the gap in employment between natives and migrants in each country.

26 "Turks and Moroccans immigrated to Belgium around the same time in the 1970s. And yet, when it comes to radicalization, the two groups couldn't be more different. Scores of Moroccans have left for Syria [to join ISIS], and there is not one recorded Turk who has followed the same path. ... Both Belgian Turks and Moroccans face labor-market discrimination in the Belgian labor market. Yet, Belgian Turks end up faring better in the labor market. ... Belgian Turks are somewhat more insulated because when they don't get a job they think they're qualified for, they turn to entrepreneurs in their own communities for help." (NPR story, April 4, 2016: "When It Comes To Radicalization In Belgium, Turks and Moroccans Are Different.")
} 
decreases the probability that the refugee will get hired by about 4.4 percentage points. Our results are not driven by refugees self-selecting into specific labor markets. Moreover, given the battery of controls and fixed effects we include, and the allocation process of refugees without U.S. ties, our estimates are not driven by strategic placement by resettlement agencies as a function of location characteristics. An important policy implication can be derived from our results. Policymakers will be able to achieve two goals at once: by providing business incentives and opportunities to tenured refugees, they can help the latter as well as just-arrived refugees. Assessing the efficiency of business support compared with other programs (language, job search) aiming at facilitating the integration of refugees into the labor markets certainly opens a path for further research. 


\section{References}

Andersson, F., M. García-Pérez, J. Haltiwanger, K. McCue, and S. Sanders (2014). Workplace concentration of immigrants. Demography 51(6), 2281-2306.

Ansala, L., O. Aslund, and M. Sarvimaki (2018). Immigration history, entry jobs and the labor market integration of immigrants. Unpublished.

Autor, D. and D. Dorn (2013). The Growth of Low Skill Service Jobs and the Polarization of the U.S. Labor Market. American Economic Review 103(5), 1553-1597.

Bandiera, O., I. Barankay, and I. Rasul (2009). Social connections and incentives in the workplace: Evidence from personnel data. Econometrica 77 (4), 1047-1094.

Bansak, K., J. Ferwerda, J. Hainmueller, A. Dillon, D. Hangartner, D. Lawrence, and J. Weinstein (2018). Improving refugee integration through data-driven algorithmic assignment. Science $359(6373)$, 325-329.

Beaman, L. A. (2012). Social Networks and the Dynamics of Labour Market Outcomes: Evidence from Refugees Resettled in the U.S. Review of Economic Studies 79(1), 128-161.

Bell, B., F. Fasani, and S. Machin (2013). Crime and immigration: Evidence from large immigrant waves. Review of Economics and Statistics 95(4), 1278-1290.

Bell, B. and S. Machin (2013). Immigration and Crime. In A. Constant and K. Zimmerman (Eds.), International Handbook on the Economics of Migration. Northampton, MA: Edward Elgar.

Borjas, G. (1994). Economics of immigration. Journal of Economic literature 32, 1667-1717.

Borjas, G. (2000). Economics of immigration. Swedish Economic Policy Review 7, 89-122.

Butcher, K. and A. Piehl (1998). Cross-City Evidence on the Relationship between Immigration and Crime. Journal of Policy Analysis and Management 17, 457-493.

Calvó-Armengol, A. and M. O. Jackson (2004, June). The effects of social networks on employment and inequality. American Economic Review 94(3), 426-454. 
Chiswick, B. (1991). Speaking, Reading, and Earnings among Low-Skilled Immigrants. Journal of Labor Economics 9(2), 149-170.

Chiswick, B. and P. Miller (1995). The endogeneity between language and earnings: International analyses. Journal of Labor Economics 13(2), 246-288.

Clemens, M. (2017). Violence, development and migration waves: Evidence from central american child migrant apprehensions. CGD Working Paper 459.

Cortes, K. (2004). Are refugees different from economic immigrants? some empirical evidence on the heterogeneity of immigrant groups in the united states. Review of Economics and Statistics 86(2), $465-480$.

Couttenier, M., V. Preotu, D. Rohner, and M. Thoenig (2016). The Violent Legacy of Victimization: Post-conflict Evidence on Asylum Seekers, Crimes and Public Policy in Switzerland. CEPR Discussion Paper 11079.

Dolphin, S. and G. Genicot. What do networks do? The role of networks on migration and coyote use, volume $=14$, year $=2010$, . Review of Development Economics (2), 343-359.

Fairlie, R. and M. Lofstrom (2013). Immigration and entrepreneurship. In B. Chiswick and P. Miller (Eds.), The Handbook on the Economics of International Migration. North-Holland Publishing.

Freedman, M., E. Owens, and S. Bohn (2018). Immigration, Employment Opportunities, and Criminal Behavior. American Economic Journal: Economic Policy 10(2), 117-151.

Giuliano, L., D. I. Levine, and J. Leonard (2009). Manager race and the race of new hires. Journal of Labor Economics $27(4), 589-631$.

Giuliano, L., D. I. Levine, and J. Leonard (2011). Racial bias in the manager-employee relationship: An analysis of quits, dismissals, and promotions at a large retail firm. Journal of Human Resources $46(1), 26-52$.

Kerr, S. and W. R. Kerr (2017). Immigrant Entrepreneurship. Harvard Business School Working paper 17-011. 
Kerr, W. R. and M. Mandorff (2015, September). Social Networks, Ethnicity, and Entrepreneurship. NBER Working Papers 21597, National Bureau of Economic Research, Inc.

Mahajan, P. and D. Yang (2017). Taken by Storm: Hurricanes, Migrant Networks, and U.S. Immigration. mimeo.

Mastrobuoni, G. and P. Pinotti (2015). Legal Status and the Criminal Activity of Immigrants. American Economic Journal: Applied Economics 7(2), 175-206.

Melitz, J. and F. Toubal (2014). Native language, spoken language, translation and trade. Journal of International Economics 93, 351-363.

Montgomery, J. D. (1991). Social networks and labor-market outcomes: Toward an economic analysis. American Economic Review 81(5), 1407-18.

Munshi, K. (2003). Networks in the modern economy: Mexican migrants in the u. s. labor market. The Quarterly Journal of Economics 118(2), 549-599.

Munshi, K. (2014a). Community Networks and Migration. In Y. Bramoulle, A. Galeotti, and B. Rogers (Eds.), The Oxford Handbook of the Economics of Networks, pp. 630-648. Oxford University Press.

Munshi, K. (2014b). Community networks and the process of development. Journal of Economic Perspectives 28(4), 49-76.

Olof Åslund, Lena Hensvik, O. N. S. (2014). Seeking similarity: How immigrants and natives manage in the labor market. Journal of Labor Economics 32(3), 405-441.

Patel, K. and F. Vella (2012, 2016/06/01). Immigrant networks and their implications for occupational choice and wages. Review of Economics and Statistics 95(4), 1249-1277.

Spenkuch, J. L. (2014). Understanding the Impact of Immigration on Crime. American Law and Economics Review 16(1), 177-219. 


\title{
Separate Appendixes with Supplemental Material for:
}

\section{Labor market integration of refugees to the United States: Do entrepreneurs in the network help?}

October 10, 2018

\begin{abstract}
This document contains a set of appendixes with supplemental material.
\end{abstract}




\section{Appendix A Tables}

Table A.1: Descriptive Statistics

\begin{tabular}{|c|c|c|c|c|c|}
\hline & Obs. & Mean & St. Dev. & Min. & Max. \\
\hline Employed & 73,578 & 0.3071842 & 0.4613296 & 0 & 1 \\
\hline Network (up to t-1) & 73,578 & 4.922013 & 6.802575 & 0 & 70.61 \\
\hline Share of self-employed $(2004) \times$ Network up to $(t-1)$ & 73,578 & 0.7873741 & 2.137421 & 0 & 14.94566 \\
\hline Share of employees $(2004) \times$ Network up to $(\mathrm{t}-1)$ & 73,578 & 2.97996 & 5.394778 & 0 & 53.02923 \\
\hline Age & 73,578 & 32.55903 & 10.92816 & 18 & 65 \\
\hline $\mathrm{Age}^{2}$ & 73,578 & 1179.513 & 813.5362 & 324 & 4225 \\
\hline Housheold size & 73,578 & 3.309386 & 2.204692 & 1 & 15 \\
\hline Male & 73,578 & 0.5785425 & 0.4937959 & 0 & 1 \\
\hline Married & 73,578 & 0.5956536 & 0.4907684 & 0 & 1 \\
\hline No Education & 73,578 & 0.3967083 & 0.4892177 & 0 & 1 \\
\hline Education: Kindergarten & 73,578 & 0.0025279 & 0.0502153 & 0 & 1 \\
\hline Education: Primary & 73,578 & 0.1738427 & 0.3789768 & 0 & 1 \\
\hline Education: Secondary & 73,578 & 0.2919895 & 0.4546806 & 0 & 1 \\
\hline Education: Intermediate & 73,578 & 0.0379325 & 0.1910344 & 0 & 1 \\
\hline Education: Pre-University & 73,578 & 0.0104515 & 0.1016976 & 0 & 1 \\
\hline Education: Technical School & 73,578 & 0.0218951 & 0.1463422 & 0 & 1 \\
\hline Professional & 73,578 & 0.0058985 & 0.0765754 & 0 & 1 \\
\hline University/College & 73,578 & 0.0657805 & 0.2478998 & 0 & 1 \\
\hline Graduate School & 73,578 & 0.0051102 & 0.0713034 & 0 & 1 \\
\hline Matching grant source of support & 73,578 & 0.4007448 & 0.4900527 & 0 & 1 \\
\hline All required core services have been provided & 73,578 & 0.990663 & 0.0961768 & 0 & 1 \\
\hline Source(s) of support from relatives or other non-government & 73,578 & 0.2078475 & 0.4057698 & 0 & 1 \\
\hline Government cash assistance support & 73,578 & 0.47767 & 0.4995045 & 0 & 1 \\
\hline Medical assistance source of support & 73,578 & 0.8246351 & 0.3802815 & 0 & 1 \\
\hline Source of support from Social Security & 73,578 & 0.01635 & 0.1268183 & 0 & 1 \\
\hline Other source(s) of support & 73,578 & 0.464541 & 0.4987445 & 0 & 1 \\
\hline Amount of R \& $\mathrm{P}$ funds spent on behalf of this family & 73,578 & 1397.566 & 1276.623 & 0 & 23687.28 \\
\hline Amount of $\mathrm{R} \& \mathrm{P}$ cash provided to this family & 73,578 & 564.7767 & 889.4204 & 0 & 9000 \\
\hline
\end{tabular}

Notes: Descriptive statistics have been computed for the most comprehensive analytical sample of table 3 , i.e. including the full set of control variables for interpretation purposes. All network variables are divided by 100 . 
Table A.1 (continued): Descriptive Statistics

\begin{tabular}{l|ccccc}
\hline & Obs. & Mean & St. Dev. & Min. & Max. \\
\hline Share of unemployed (2004) $\times$ Network up to (t-1) & 63,772 & 19.99498 & 43.67504 & 0 & 609.5593 \\
Linguistic network & 73,578 & 8.707178 & 8.338295 & 0 & 71.75341 \\
Share of self-employed (2004) in Ling. network & 73,578 & 1.013144 & 2.239999 & 0 & 15.83355 \\
$\times$ Linguistic Network up to (t-1) & & & & & \\
Religious network & 73,578 & 17.25106 & 14.19942 & 0 & 72.61958 \\
Share of self-employed (2004) in rel. network & 73,578 & 1.467041 & 2.595386 & 0 & 16.38391 \\
$\times$ Religious Network up to (t-1) & & & & & \\
\hline
\end{tabular}

Notes: Descriptive statistics have been computed for the most comprehensive analytical sample of table 3, i.e. including the full set of control variables for interpretation purposes. All network variables are divided by 100 .

Table A.2: The impact of the network of migrants

\begin{tabular}{l|ccccc}
\hline & $(1)$ & $(2)$ & $(3)$ & $(4)$ & $(5)$ \\
Dep. var. & \multicolumn{5}{c}{ Employed } \\
\hline Network (up to t-1) & $-0.0001^{* *}$ & 0.0000 & 0.0000 & -0.0000 & -0.0000 \\
& $(0.000)$ & $(0.000)$ & $(0.000)$ & $(0.000)$ & $(0.000)$ \\
Observations & 75,832 & 75,645 & 75,645 & 75,645 & 73,578 \\
R-squared & 0.130 & 0.202 & 0.271 & 0.276 & 0.357 \\
\hline \hline Year, nationality, and CZ FE & $\mathrm{Y}$ & $\mathrm{N}$ & $\mathrm{N}$ & $\mathrm{N}$ & $\mathrm{N}$ \\
CZ-Year FE & $\mathrm{N}$ & $\mathrm{Y}$ & $\mathrm{Y}$ & $\mathrm{Y}$ & $\mathrm{Y}$ \\
Nationality-Year FE & $\mathrm{N}$ & $\mathrm{Y}$ & $\mathrm{Y}$ & $\mathrm{Y}$ & $\mathrm{Y}$ \\
CZ-Nationality FE & $\mathrm{N}$ & $\mathrm{Y}$ & $\mathrm{Y}$ & $\mathrm{Y}$ & $\mathrm{Y}$ \\
Ind. Controls (1) & $\mathrm{N}$ & $\mathrm{N}$ & $\mathrm{Y}$ & $\mathrm{Y}$ & $\mathrm{Y}$ \\
Ind. Controls (2) & $\mathrm{N}$ & $\mathrm{N}$ & $\mathrm{N}$ & $\mathrm{Y}$ & $\mathrm{Y}$ \\
Ind. Controls (3) & $\mathrm{N}$ & $\mathrm{N}$ & $\mathrm{N}$ & $\mathrm{N}$ & $\mathrm{Y}$ \\
\hline
\end{tabular}

Notes: Standard errors clustered (multi-way) at the commuting zone and nationality levels in parentheses. ${ }^{*},{ }^{* *},{ }^{* *}$ : significant at 10\%,5\%, and 1\%, respectively. All network variables are divided by 100 . Controls are described below Table 1. 
Table A.3: The impact of the network: Estimates of coefficients of individual-level covariates (Part 1)

\begin{tabular}{|c|c|c|c|c|c|}
\hline \multirow[b]{2}{*}{ Dep. var. } & $(1)$ & $(2)$ & $(3)$ & $(4)$ & $(5)$ \\
\hline & \multicolumn{5}{|c|}{ Employed } \\
\hline \multirow[t]{2}{*}{ Network (up to t-1) } & -0.0009 & 0.0016 & 0.0026 & 0.0029 & 0.0042 \\
\hline & $(0.002)$ & $(0.004)$ & $(0.004)$ & $(0.005)$ & $(0.005)$ \\
\hline \multirow[t]{2}{*}{ Age } & & & $0.0171^{* * *}$ & $0.0170^{* * *}$ & $0.0128^{* * *}$ \\
\hline & & & $(0.002)$ & $(0.002)$ & $(0.002)$ \\
\hline \multirow[t]{2}{*}{$\mathrm{Age}^{2}$} & & & $-0.0003^{* * *}$ & $-0.0003^{* * *}$ & $-0.0002^{* * *}$ \\
\hline & & & $(0.000)$ & $(0.000)$ & $(0.000)$ \\
\hline \multirow[t]{2}{*}{ Household size } & & & $-0.0183^{* * *}$ & $-0.0161^{* * *}$ & $-0.0138^{* * *}$ \\
\hline & & & $(0.002)$ & $(0.002)$ & $(0.003)$ \\
\hline \multirow[t]{2}{*}{ Male } & & & $0.1954^{* * *}$ & $0.1907^{* * *}$ & $0.1809^{* * *}$ \\
\hline & & & $(0.015)$ & $(0.015)$ & $(0.017)$ \\
\hline \multirow[t]{2}{*}{ Married } & & & $-0.0129^{*}$ & $-0.0129 *$ & $-0.0349 * * *$ \\
\hline & & & $(0.007)$ & $(0.007)$ & $(0.007)$ \\
\hline Education & & & & 0.0030 & -0.0004 \\
\hline Kindergarten & & & & $(0.013)$ & $(0.016)$ \\
\hline Education & & & & -0.0016 & -0.0083 \\
\hline Primary & & & & $(0.009)$ & $(0.007)$ \\
\hline Education & & & & $0.0584^{* * *}$ & $0.0424^{* * *}$ \\
\hline Secondary & & & & $(0.008)$ & $(0.007)$ \\
\hline Education & & & & $0.0326^{* *}$ & $0.0239^{* *}$ \\
\hline Intermediate & & & & $(0.013)$ & $(0.011)$ \\
\hline Education & & & & $0.1449^{* * *}$ & $0.1098^{* * *}$ \\
\hline Pre-University & & & & $(0.031)$ & $(0.029)$ \\
\hline Education & & & & $0.0773^{* * *}$ & $0.0597 * * *$ \\
\hline Technical School & & & & $(0.021)$ & $(0.017)$ \\
\hline
\end{tabular}


Table A.3 (continued) The impact of the network: Estimates of coefficients of individual-level covariates (Part 2)

\begin{tabular}{|c|c|c|c|c|c|}
\hline & $(1)$ & $(2)$ & $(3)$ & $(4)$ & $(5)$ \\
\hline Professional & & & & $\begin{array}{c}0.0815^{* *} \\
(0.032)\end{array}$ & $\begin{array}{c}0.0707^{* *} \\
(0.032)\end{array}$ \\
\hline University/College & & & & $\begin{array}{c}0.1100^{* * *} \\
(0.029)\end{array}$ & $\begin{array}{c}0.0841^{* * *} \\
(0.024)\end{array}$ \\
\hline Graduate School & & & & $\begin{array}{c}0.0938^{* * *} \\
(0.026)\end{array}$ & $\begin{array}{c}0.0539^{*} \\
(0.027)\end{array}$ \\
\hline Matching grant & & & & & $-0.1853^{* * *}$ \\
\hline source of support & & & & & $(0.017)$ \\
\hline All core services & & & & & $\begin{array}{c}0.0875^{* * *} \\
(0.021)\end{array}$ \\
\hline $\begin{array}{l}\text { Source(s) of support } \\
\text { from others }\end{array}$ & & & & & $\begin{array}{c}-0.0659^{* * *} \\
(0.017)\end{array}$ \\
\hline $\begin{array}{l}\text { Government cash } \\
\text { assistance support }\end{array}$ & & & & & $\begin{array}{c}-0.3596^{* * *} \\
(0.021)\end{array}$ \\
\hline Medical assistance & & & & & $-0.0552^{* * *}$ \\
\hline source of support & & & & & $(0.013)$ \\
\hline Source of support & & & & & $-0.0410^{*}$ \\
\hline from Social Security & & & & & $(0.024)$ \\
\hline Other source(s) of support & & & & & $\begin{array}{c}-0.0708^{* * *} \\
(0.012)\end{array}$ \\
\hline Amount of $\mathrm{R} \& \mathrm{P}$ funds & & & & & $\begin{array}{l}0.0000^{*} \\
(0.000)\end{array}$ \\
\hline Amount of $\mathrm{R} \& \mathrm{P}$ cash & & & & & $\begin{array}{l}0.0000 \\
(0.000)\end{array}$ \\
\hline Observations & 75,832 & 75,645 & 75,645 & 75,645 & 73,578 \\
\hline R-squared & 0.130 & 0.202 & 0.271 & 0.276 & 0.357 \\
\hline
\end{tabular}


Table A.4: Main results with alternative standard errors

\begin{tabular}{|c|c|c|c|c|c|}
\hline & $(1)$ & $(2)$ & $(3)$ & $(4)$ & $(5)$ \\
\hline Dep. var. & \multicolumn{5}{|c|}{ Employed } \\
\hline Network (up to t-1) & -0.0021 & -0.0010 & -0.0011 & -0.0009 & 0.0008 \\
\hline (CZ clustered) & $(0.002)$ & $(0.005)$ & $(0.005)$ & $(0.005)$ & $(0.005)$ \\
\hline (CZ \& Year clustered) & $(0.002)$ & $(0.006)$ & $(0.006)$ & $(0.007)$ & $(0.006)$ \\
\hline (CZ \& Year clustered, Cameron et al. pvalue) & {$[0.214]$} & {$[0.882]$} & {$[0.889]$} & {$[0.909]$} & {$[0.876]$} \\
\hline Share of self.-employed (2004) & 0.0035 & 0.0125 & 0.0162 & 0.0166 & 0.0153 \\
\hline \multicolumn{6}{|l|}{$\times$ Network up to $(\mathrm{t}-1)$} \\
\hline (CZ clustered) & $(0.004)$ & $(0.004)^{* * *}$ & $(0.005)^{* * *}$ & $(0.004)^{* * *}$ & $(0.005)^{* * *}$ \\
\hline (CZ \& Year clustered) & $(0.003)$ & $(0.004)^{* *}$ & $(0.005)^{* *}$ & $(0.006)^{* *}$ & $(0.008)$ \\
\hline (CZ \& Year clustered, Cameron et al. pvalue) & {$[0.584]$} & {$[0.0798]^{*}$} & {$[0.0818]^{*}$} & {$[0.0792]^{*}$} & {$[0.136]$} \\
\hline Share of employees (2004) & 0.0007 & -0.0065 & -0.0079 & -0.0081 & -0.0077 \\
\hline \multicolumn{6}{|l|}{$\times$ Network up to $(\mathrm{t}-1)$} \\
\hline (CZ clustered) & $(0.003)$ & $(0.004)$ & $(0.005)^{*}$ & $(0.004)^{*}$ & $(0.005)$ \\
\hline (CZ \& Year clustered) & $(0.003)$ & $(0.003)$ & $(0.004)$ & $(0.005)$ & $(0.006)$ \\
\hline (CZ $\&$ Year clustered, Cameron et al. pvalue) & {$[0.820]$} & {$[0.0929]^{*}$} & {$[0.109]$} & {$[0.0995]^{*}$} & {$[0.155]$} \\
\hline Observations & 75,832 & 75,645 & 75,645 & 75,645 & 73,578 \\
\hline R-squared & 0.130 & 0.202 & 0.271 & 0.276 & 0.357 \\
\hline Year, nationality, and CZ FE & $\mathrm{Y}$ & $\mathrm{N}$ & $\mathrm{N}$ & $\mathrm{N}$ & $\mathrm{N}$ \\
\hline CZ-Year FE & $\mathrm{N}$ & $\mathrm{Y}$ & $\mathrm{Y}$ & $\mathrm{Y}$ & $\mathrm{Y}$ \\
\hline Nationality-Year FE & $\mathrm{N}$ & $\mathrm{Y}$ & $\mathrm{Y}$ & $\mathrm{Y}$ & $\mathrm{Y}$ \\
\hline CZ-Nationality FE & $\mathrm{N}$ & $\mathrm{Y}$ & $\mathrm{Y}$ & $\mathrm{Y}$ & $\mathrm{Y}$ \\
\hline Ind. Controls (1) & $\mathrm{N}$ & $\mathrm{N}$ & $\mathrm{Y}$ & $\mathrm{Y}$ & $\mathrm{Y}$ \\
\hline Ind. Controls (2) & $\mathrm{N}$ & $\mathrm{N}$ & $\mathrm{N}$ & $\mathrm{Y}$ & $\mathrm{Y}$ \\
\hline Ind. Controls (3) & $\mathrm{N}$ & $\mathrm{N}$ & $\mathrm{N}$ & $\mathrm{N}$ & $\mathrm{Y}$ \\
\hline
\end{tabular}

Notes: Clustered standard errors in parentheses. ${ }^{*},{ }^{* *},{ }^{* * *}$ : significant at $10 \%, 5 \%$, and $1 \%$, respectively. Control variables are described below Table 1. 
Table A.5: The impact of the network of migrants (2SLS)

\begin{tabular}{|c|c|c|c|c|c|c|}
\hline & (1) & $(2)$ & $(3)$ & $(4)$ & $(5)$ & $(6)$ \\
\hline & OLS & OLS & OLS & 2SLS & 2SLS & 2SLS \\
\hline Dep. var. & \multicolumn{6}{|c|}{ Employed } \\
\hline Panel A & \multicolumn{6}{|c|}{ Impact of business owners } \\
\hline \multirow{2}{*}{ Migration (up to t-1) } & -0.0005 & -0.0005 & -0.0000 & -0.0043 & -0.0041 & -0.0018 \\
\hline & $(0.001)$ & $(0.001)$ & $(0.001)$ & $(0.003)$ & $(0.004)$ & $(0.005)$ \\
\hline Share of self-employed(2004) & 0.0040 & 0.0039 & 0.0000 & $0.0267^{* *}$ & $0.0280^{* * *}$ & $0.0284^{* *}$ \\
\hline$\times$ Migration up to $(\mathrm{t}-1)$ & $(0.004)$ & $(0.005)$ & $(0.004)$ & $(0.010)$ & $(0.010)$ & $(0.012)$ \\
\hline Observations & 75,645 & 75,645 & 73,578 & 75,645 & 75,645 & 73,578 \\
\hline R-squared & 0.271 & 0.276 & 0.357 & 0.270 & 0.275 & 0.356 \\
\hline Kleibergen-Paap rk Wald F & & & & 48.63 & 48.60 & 36 \\
\hline Panel B & \multicolumn{6}{|c|}{ Impact of business owners and employees } \\
\hline \multirow[t]{2}{*}{ Migration (up to t-1) } & $-0.0023^{* *}$ & $-0.0021^{* *}$ & $-0.0019^{*}$ & 0.0014 & 0.0016 & 0.0019 \\
\hline & $(0.001)$ & $(0.001)$ & $(0.001)$ & $(0.004)$ & $(0.005)$ & $(0.005)$ \\
\hline Share of self-employed (2004) & 0.0026 & 0.0026 & -0.0014 & $0.0563^{* * *}$ & $0.0579 * * *$ & $0.0558^{* * *}$ \\
\hline$\times$ Migration up to $(\mathrm{t}-1)$ & $(0.005)$ & $(0.005)$ & $(0.005)$ & $(0.002)$ & $(0.007)$ & $(0.014)$ \\
\hline Share of employees (2004) & $0.0030^{* *}$ & $0.0027^{*}$ & 0.0030 & $-0.0306^{* * *}$ & $-0.0309^{* * *}$ & $-0.0287^{* *}$ \\
\hline$\times$ Migration up to $(\mathrm{t}-1)$ & $(0.001)$ & $(0.001)$ & $(0.002)$ & $(0.008)$ & $(0.008)$ & $(0.012)$ \\
\hline Observations & 75,645 & 75,645 & 73,578 & 75,645 & 75,645 & 73,578 \\
\hline R-squared & 0.271 & 0.276 & 0.357 & 0.248 & 0.253 & 0.339 \\
\hline Kleibergen-Paap rk Wald F & & & & 8.383 & 8.369 & 4.985 \\
\hline CZ-Year FE & $\mathrm{Y}$ & $\mathrm{Y}$ & $\mathrm{Y}$ & $\mathrm{Y}$ & $\mathrm{Y}$ & $\mathrm{Y}$ \\
\hline Nationality-Year FE & $\mathrm{Y}$ & $\mathrm{Y}$ & $\mathrm{Y}$ & $\mathrm{Y}$ & $\mathrm{Y}$ & $\mathrm{Y}$ \\
\hline CZ-Nationality FE & $\mathrm{Y}$ & $\mathrm{Y}$ & $\mathrm{Y}$ & $\mathrm{Y}$ & $\mathrm{Y}$ & $\mathrm{Y}$ \\
\hline Ind. Controls (1) & $\mathrm{Y}$ & $\mathrm{Y}$ & $\mathrm{Y}$ & $\mathrm{Y}$ & $\mathrm{Y}$ & $\mathrm{Y}$ \\
\hline Ind. Controls (2) & $\mathrm{N}$ & $\mathrm{Y}$ & $\mathrm{Y}$ & $\mathrm{N}$ & $\mathrm{Y}$ & $\mathrm{Y}$ \\
\hline Ind. Controls (3) & $\mathrm{N}$ & $\mathrm{N}$ & $\mathrm{Y}$ & $\mathrm{N}$ & $\mathrm{N}$ & $\mathrm{Y}$ \\
\hline
\end{tabular}

Notes: Standard errors clustered at the commuting zone and nationality levels in parentheses. Due to a large number of clusters, the Kleibergen-Paap rk Wald F tests were computed based on an alternative clustering (commuting zone-year). ${ }^{*},{ }^{* *},{ }^{* * *}$ : significant at $10 \%, 5 \%$, and $1 \%$, respectively. All network variables are divided by 100. Controls are described below Table 1 . 
Table A.7: The impact of business owners and employees in the network, using Share of self-employed and Share of employees at (t-1)

\begin{tabular}{|c|c|c|c|c|c|}
\hline & (1) & $(2)$ & $(3)$ & $(4)$ & $(5)$ \\
\hline Dep. var. & \multicolumn{5}{|c|}{ Employed } \\
\hline Panel A & \multicolumn{5}{|c|}{ Impact of business owners $(t-1)$} \\
\hline \multirow[t]{2}{*}{ Network (up to t-1) } & -0.0016 & 0.0003 & 0.0012 & 0.0015 & 0.0023 \\
\hline & $(0.002)$ & $(0.004)$ & $(0.004)$ & $(0.004)$ & $(0.004)$ \\
\hline Share of self-employed $(t-1)$ & 0.0051 & $0.0155^{* *}$ & $0.0157^{*}$ & $0.0149^{*}$ & 0.0104 \\
\hline$\times$ Network up to $(t-1$ & $(0.005)$ & $(0.007)$ & $(0.008)$ & $(0.008)$ & $(0.009)$ \\
\hline Observations & 75,832 & 75,645 & 75,645 & 75,645 & 73,578 \\
\hline R-squared & 0.131 & 0.202 & 0.271 & 0.276 & 0.357 \\
\hline Panel B & \multicolumn{5}{|c|}{ Impact of business owners and employees $(t-1$} \\
\hline \multirow[t]{2}{*}{ Network (up to t-1) } & -0.0008 & 0.0018 & 0.0033 & 0.0041 & 0.0047 \\
\hline & $(0.003)$ & $(0.005)$ & $(0.005)$ & $(0.005)$ & $(0.005)$ \\
\hline Share of self-employed $(t-1)$ & 0.0059 & $0.0162^{* *}$ & $0.0170^{*}$ & $0.0164^{*}$ & 0.0118 \\
\hline$\times$ Network up to $(t-1)$ & $(0.004)$ & $(0.008)$ & $(0.009)$ & $(0.009)$ & $(0.009)$ \\
\hline Share of employees $(t-1)$ & -0.0014 & -0.0028 & -0.0041 & -0.0049 & -0.0047 \\
\hline$\times$ Network up to $(t-1)$ & $(0.003)$ & $(0.003)$ & $(0.003)$ & $(0.003)$ & $(0.005)$ \\
\hline Observations & 75,832 & 75,645 & 75,645 & 75,645 & 73,578 \\
\hline R-squared & 0.131 & 0.202 & 0.271 & 0.276 & 0.357 \\
\hline Year, nationality, and CZ FE & $\mathrm{Y}$ & $\mathrm{N}$ & $\mathrm{N}$ & $\mathrm{N}$ & $\mathrm{N}$ \\
\hline CZ-Year FE & $\mathrm{N}$ & $\mathrm{Y}$ & $\mathrm{Y}$ & $\mathrm{Y}$ & $\mathrm{Y}$ \\
\hline Nationality-Year FE & $\mathrm{N}$ & $\mathrm{Y}$ & $\mathrm{Y}$ & $\mathrm{Y}$ & $\mathrm{Y}$ \\
\hline CZ-Nationality FE & $\mathrm{N}$ & $\mathrm{Y}$ & $\mathrm{Y}$ & $\mathrm{Y}$ & $\mathrm{Y}$ \\
\hline Ind. Controls (1) & $\mathrm{N}$ & $\mathrm{N}$ & $\mathrm{Y}$ & $\mathrm{Y}$ & $\mathrm{Y}$ \\
\hline Ind. Controls (2) & $\mathrm{N}$ & $\mathrm{N}$ & $\mathrm{N}$ & $\mathrm{Y}$ & $\mathrm{Y}$ \\
\hline Ind. Controls (3) & $\mathrm{N}$ & $\mathrm{N}$ & $\mathrm{N}$ & $\mathrm{N}$ & $\mathrm{Y}$ \\
\hline
\end{tabular}

Notes: Standard errors clustered at the commuting zone and nationality levels in parentheses.

Time-varying components of the interactions terms (not captured by CZ-year fixed effects) are also included in the regressions. ${ }^{*},{ }^{* *},{ }^{* * *}$ : significant at $10 \%, 5 \%$, and $1 \%$, respectively. Control variables are described below Table 1. 
Table A.6: Robustness to the role of tenured members in the networks

\begin{tabular}{|c|c|c|c|}
\hline & (1) & $(2)$ & $(3)$ \\
\hline Dep. var. & \multicolumn{3}{|c|}{ Employed } \\
\hline Panel A & \multicolumn{3}{|c|}{ Controlling for migration networks (up to t-3) } \\
\hline Share of self-employed (2004) & $0.0162^{* * *}$ & $0.0167^{* * *}$ & $0.0153^{* * *}$ \\
\hline$\times$ Network up to $(\mathrm{t}-1)$ & $(0.001)$ & $(0.002)$ & $(0.005)$ \\
\hline Share of employees (2004) & $-0.0079 * *$ & $-0.0081^{* *}$ & $-0.0077^{*}$ \\
\hline$\times$ Network (up to t-1) & $(0.004)$ & $(0.004)$ & $(0.004)$ \\
\hline \multirow[t]{2}{*}{ Migration (t-3) } & 0.0000 & 0.0001 & 0.0001 \\
\hline & $(0.001)$ & $(0.001)$ & $(0.001)$ \\
\hline Observations & 75,645 & 75,645 & 73,578 \\
\hline R-squared & 0.271 & 0.276 & 0.357 \\
\hline Panel B & \multicolumn{3}{|c|}{ Considering the network of tenured refugee } \\
\hline Share of self-employed (2004) & $0.0003^{* * *}$ & $0.0003^{* * *}$ & $0.0002^{* *}$ \\
\hline$\times$ Network up to $(\mathrm{t}-3)$ & $(0.000)$ & $(0.000)$ & $(0.000)$ \\
\hline Share of employees (2004) & -0.0001 & -0.0001 & -0.0001 \\
\hline$\times$ Network up to $(\mathrm{t}-3)$ & $(0.000)$ & $(0.000)$ & $(0.000)$ \\
\hline Observations & 75,645 & 75,645 & 73,578 \\
\hline R-squared & 0.271 & 0.276 & 0.357 \\
\hline CZ-Year, Nationality-Year \& CZ-Nationality FE & $\mathrm{Y}$ & $\mathrm{Y}$ & $\mathrm{Y}$ \\
\hline Ind. Controls (1) & $\mathrm{Y}$ & Y & $\mathrm{Y}$ \\
\hline Ind. Controls (2) & $\mathrm{N}$ & $\mathrm{Y}$ & $\mathrm{Y}$ \\
\hline Ind. Controls (3) & $\mathrm{N}$ & $\mathrm{N}$ & $\mathrm{Y}$ \\
\hline
\end{tabular}

Notes: Standard errors clustered at the commuting zone and nationality level in parentheses. ${ }^{*},{ }^{* *},{ }^{* * *}$ : significant at $10 \%, 5 \%$, and $1 \%$, respectively. All network variables are divided by 100 . The Network (up to t-1) and the Network (up to t-3) variables are included in Panels A and B, respectively and remain insignificant in both panels. The three sets of individual control variables are described under Table 1. 
Table A.8: The impact of business owners and employees in the network, dividing all network variables by the network population in thousands (at $t-1)$

\begin{tabular}{|c|c|c|c|c|c|}
\hline & $(1)$ & $(2)$ & $(3)$ & $(4)$ & $(5)$ \\
\hline Dep. var. & \multicolumn{5}{|c|}{ Employed } \\
\hline Panel A & \multicolumn{5}{|c|}{ Impact of business owners (by 1,000 pop. at $t-1$ ) } \\
\hline \multirow[t]{2}{*}{ Network (up to t-1) per 1,000 pop. } & 0.0065 & -2.7600 & -3.7315 & -3.7289 & -3.5636 \\
\hline & $(0.000)$ & $(2.691)$ & $(2.929)$ & $(3.009)$ & $(2.529)$ \\
\hline Share of self-employed $(t-1)$ & 4.0016 & $17.1767^{* *}$ & $20.3885^{* * *}$ & $21.5375^{* * *}$ & $18.6504^{* *}$ \\
\hline$\times$ Network up to $(t-1)$ per 1,000 pop. & $(4.233)$ & $(6.541)$ & $(7.625)$ & $(7.646)$ & $(7.625)$ \\
\hline Observations & 75,759 & 75,574 & 75,574 & 75,574 & 73,507 \\
\hline R-squared & 0.130 & 0.202 & 0.271 & 0.276 & 0.357 \\
\hline Panel B & \multicolumn{5}{|c|}{ Impact of business owners and employees (by 1,000 pop. at $t-1$ ) } \\
\hline \multirow[t]{2}{*}{ Network (up to t-1) per 1,000 pop. } & $0.0066^{* * *}$ & -2.1686 & -3.1543 & -3.0711 & -3.0481 \\
\hline & $(0.000)$ & $(3.012)$ & $(3.323)$ & $(3.363)$ & $(2.643)$ \\
\hline Share of self-employed $(t-1)$ & $8.1070^{* *}$ & $18.9688^{* * *}$ & $22.1374^{* * *}$ & $23.5298^{* * *}$ & $20.0602^{* * *}$ \\
\hline$\times$ Network up to $(t-1)$ & $(4.018)$ & $(6.925)$ & $(8.141)$ & $(8.133)$ & $(8.428)$ \\
\hline Share of employees $(t-1)$ & $-3.8351^{* * *}$ & -2.4079 & -2.3498 & -2.6774 & -1.8964 \\
\hline$\times$ Network up to $(t-1)$ & $(1.018)$ & $(3.726)$ & $(2.522)$ & $(3.448)$ & $(3.509)$ \\
\hline Observations & 75,759 & 75,574 & 75,574 & 75,574 & 73,507 \\
\hline R-squared & 0.131 & 0.202 & 0.271 & 0.276 & 0.357 \\
\hline Year, nationality, and CZ FE & $\mathrm{Y}$ & $\mathrm{N}$ & $\mathrm{N}$ & $\mathrm{N}$ & $\mathrm{N}$ \\
\hline CZ-Year FE & $\mathrm{N}$ & $\mathrm{Y}$ & $\mathrm{Y}$ & Y & $\mathrm{Y}$ \\
\hline Nationality-Year FE & $\mathrm{N}$ & $\mathrm{Y}$ & $\mathrm{Y}$ & $\mathrm{Y}$ & $\mathrm{Y}$ \\
\hline CZ-Nationality FE & $\mathrm{N}$ & $\mathrm{Y}$ & $\mathrm{Y}$ & $\mathrm{Y}$ & $\mathrm{Y}$ \\
\hline Ind. Controls (1) & $\mathrm{N}$ & $\mathrm{N}$ & $\mathrm{Y}$ & $\mathrm{Y}$ & $\mathrm{Y}$ \\
\hline Ind. Controls (2) & $\mathrm{N}$ & $\mathrm{N}$ & $\mathrm{N}$ & $\mathrm{Y}$ & $\mathrm{Y}$ \\
\hline Ind. Controls (3) & $\mathrm{N}$ & $\mathrm{N}$ & $\mathrm{N}$ & $\mathrm{N}$ & $\mathrm{Y}$ \\
\hline
\end{tabular}

Notes: Standard errors clustered at the commuting zone and nationality level in parentheses. ${ }^{*},{ }^{* *},{ }^{* * *}$ : significant at 10\%, 5\%, and 1\%, respectively. Control variables are described below Table 1 . The commuting zone population at time $t-1$ is constructed by removing from our sample of individuals aged 18-65, those known to have arrived between $\mathrm{t}-1$ and $\mathrm{t}$. 
Table A.9: The impact of refugees on native population

\begin{tabular}{l|c}
\hline Panel A & $(1)$ \\
Dep. var. & Native displacement \\
Network (up to t-1) & Population \\
& -6.8217 \\
Observations & $(16.112)$ \\
R-squared & 661 \\
\hline Panel B & 0.999 \\
Network (up to t-1) & -2.7539 \\
& $(3.653)$ \\
Observations & 661 \\
R-squared & 0.998 \\
\hline Panel C & Native displacement of employees \\
Network (up to t-1) & Y \\
\hline Observations & -8.7836 \\
R-squared & $(25.107)$ \\
\hline \hline CZ FE & 661 \\
Year FE & 0.999 \\
\hline
\end{tabular}

Notes: Robust standard errors clustered at the commuting zone level in parentheses. ${ }^{*},{ }^{* *},{ }^{* * *}$ : significant at $10 \%, 5 \%$, and 1\%, respectively. All network variables are divided by 100 . 
Table A.10: Controlling for other networks

\begin{tabular}{|c|c|c|c|c|c|}
\hline & (1) & $(2)$ & $(3)$ & $(4)$ & $(5)$ \\
\hline Dep. var. & \multicolumn{5}{|c|}{ Employed } \\
\hline Panel A & \multicolumn{5}{|c|}{ Impact of business owners } \\
\hline \multirow[t]{2}{*}{ Network (up to t-1) } & -0.0020 & -0.0028 & -0.0033 & -0.0032 & -0.0014 \\
\hline & $(0.001)$ & $(0.003)$ & $(0.003)$ & $(0.003)$ & $(0.004)$ \\
\hline Share of self. employ. (2004) & $0.0043^{* *}$ & $0.0078^{* * *}$ & $0.0105^{* * *}$ & $0.0108^{* * *}$ & $0.0098^{* *}$ \\
\hline$\times$ Network up to $(\mathrm{t}-1)$ & $(0.002)$ & $(0.002)$ & $(0.003)$ & $(0.003)$ & $(0.005)$ \\
\hline Share of self. employ. (2004) & -0.0000 & 0.0001 & 0.0001 & 0.0001 & 0.0001 \\
\hline$\times$ Other Network up to $(\mathrm{t}-1)$ & $(0.000)$ & $(0.000)$ & $(0.000)$ & $(0.000)$ & $(0.000)$ \\
\hline Observations & 76,414 & 75,806 & 75,806 & 75,806 & 73,738 \\
\hline R-squared & 0.133 & 0.204 & 0.273 & 0.278 & 0.358 \\
\hline Panel B & \multicolumn{5}{|c|}{ Impact of business owners and employees } \\
\hline \multirow[t]{2}{*}{ Network (up to t-1) } & -0.0023 & -0.0007 & -0.0008 & -0.0006 & 0.0011 \\
\hline & $(0.002)$ & $(0.005)$ & $(0.005)$ & $(0.005)$ & $(0.005)$ \\
\hline Share of self. employ. (2004) & 0.0039 & $0.0123^{* * *}$ & $0.0161^{* * *}$ & $0.0165^{* * *}$ & $0.0152^{* * *}$ \\
\hline$\times$ Network up to $(\mathrm{t}-1)$ & $(0.003)$ & $(0.001)$ & $(0.001)$ & $(0.003)$ & $(0.005)$ \\
\hline Share of employ. (2004) & 0.0007 & $-0.0066^{*}$ & $-0.0080^{* *}$ & $-0.0081^{* *}$ & $-0.0078^{*}$ \\
\hline$\times$ Network up to $(\mathrm{t}-1)$ & $(0.003)$ & $(0.004)$ & $(0.004)$ & $(0.004)$ & $(0.004)$ \\
\hline Share of self. employ. (2004) & -0.0000 & $0.0004^{* * *}$ & $0.0004^{* * *}$ & $0.0004^{* * *}$ & $0.0004^{* *}$ \\
\hline$\times$ Other Network up to $(\mathrm{t}-1)$ & $(0.000)$ & $(0.000)$ & $(0.000)$ & $(0.000)$ & $(0.000)$ \\
\hline Share of empl. (2004) & 0.0000 & $-0.0001^{* *}$ & $-0.0001^{* * *}$ & -0.0001 & $-0.0001^{*}$ \\
\hline$\times$ Other Network up to $(\mathrm{t}-1)$ & $(0.000)$ & $(0.000)$ & $(0.000)$ & $(0.000)$ & $(0.000)$ \\
\hline Observations & 76,414 & 75,806 & 75,806 & 75,806 & 73,738 \\
\hline R-squared & 0.133 & 0.204 & 0.273 & 0.278 & 0.359 \\
\hline Year, nationality, and CZ FE & $\mathrm{Y}$ & $\mathrm{N}$ & $\mathrm{N}$ & $\mathrm{N}$ & $\mathrm{N}$ \\
\hline CZ-Year, Nat.-Year, CZ-Nat. FE & $\mathrm{N}$ & $\mathrm{Y}$ & $\mathrm{Y}$ & $\mathrm{Y}$ & $\mathrm{Y}$ \\
\hline Ind. Controls (1) & $\mathrm{N}$ & $\mathrm{N}$ & $\mathrm{Y}$ & $\mathrm{Y}$ & $\mathrm{Y}$ \\
\hline Ind. Controls (2) & $\mathrm{N}$ & $\mathrm{N}$ & $\mathrm{N}$ & $\mathrm{Y}$ & $\mathrm{Y}$ \\
\hline Ind. Controls (3) & $\mathrm{N}$ & $\mathrm{N}$ & $\mathrm{N}$ & $\mathrm{N}$ & $\mathrm{Y}$ \\
\hline
\end{tabular}

Notes: Standard errors clustered at the commuting zone and nationality levels in parentheses. ${ }^{*},{ }^{* *},{ }^{* * *}$ : significant at $10 \%, 5 \%$, and $1 \%$, respectively. The size of the other networks (the component "Other Networks up to (t-1)") is not introduced separately since its variation is captured by the CZ-year fixed effects. Control variables are described below Table 1. 


\section{Appendix B Figures}

Figure B.1. Size of networks of refugees (without U.S. ties) across commuting zones within the United States, in 2010

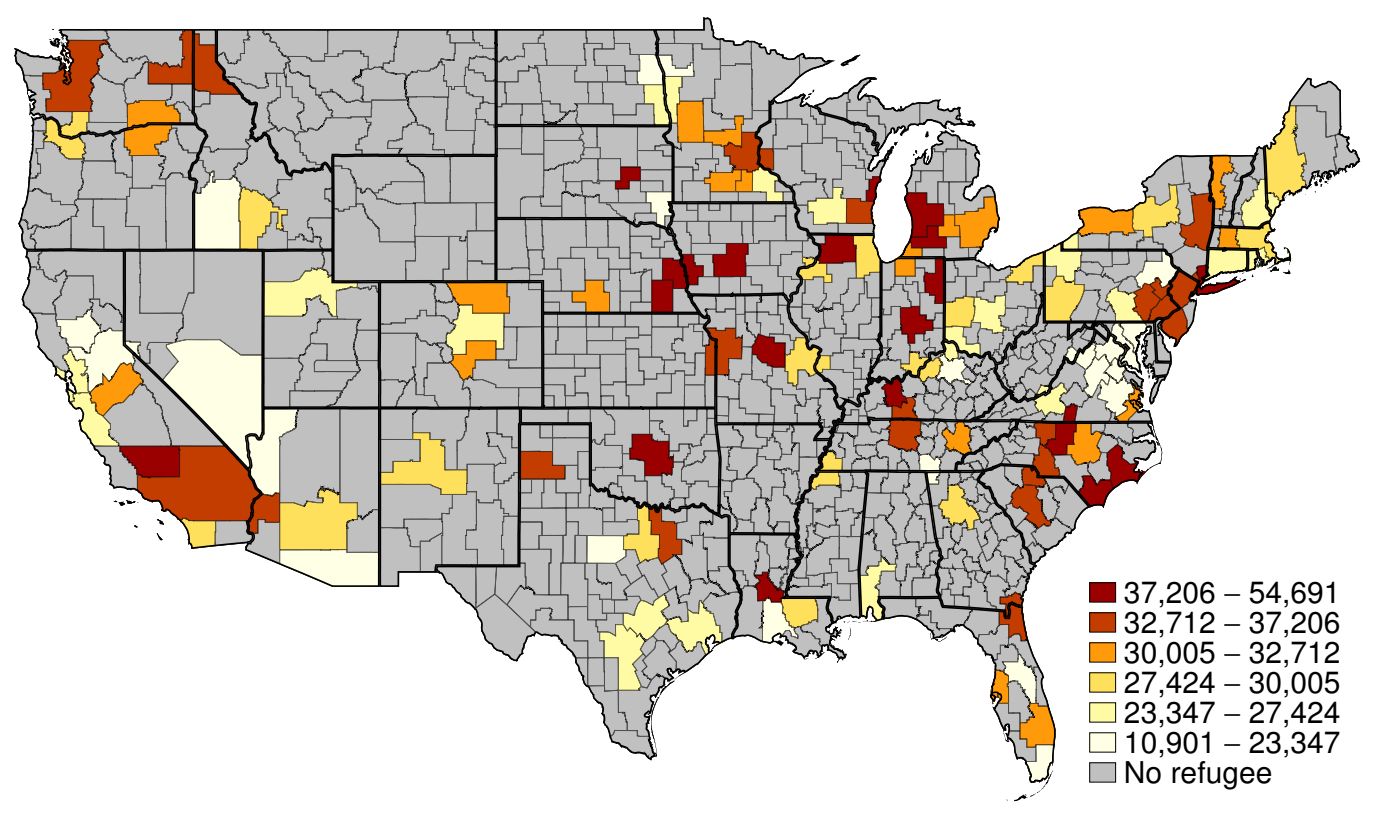

Note: Only communities with individual observations are considered.

Source: WRAPS. 
Figure B.2. The impact of network size on the probability of employment (Vietnam, Russia, Sudan, Iran
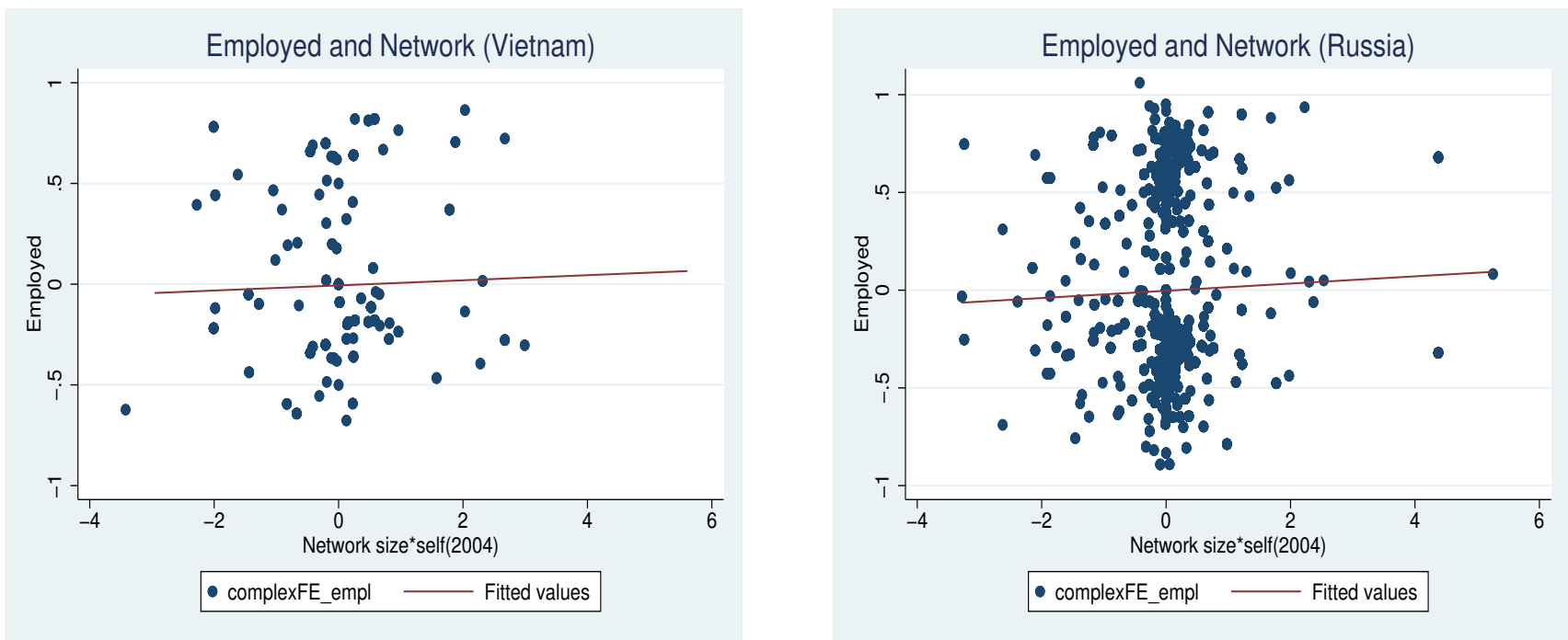

(a) Correlation between employment and network size (b) Correlation between employment and network size (Vietnam) (Russia)
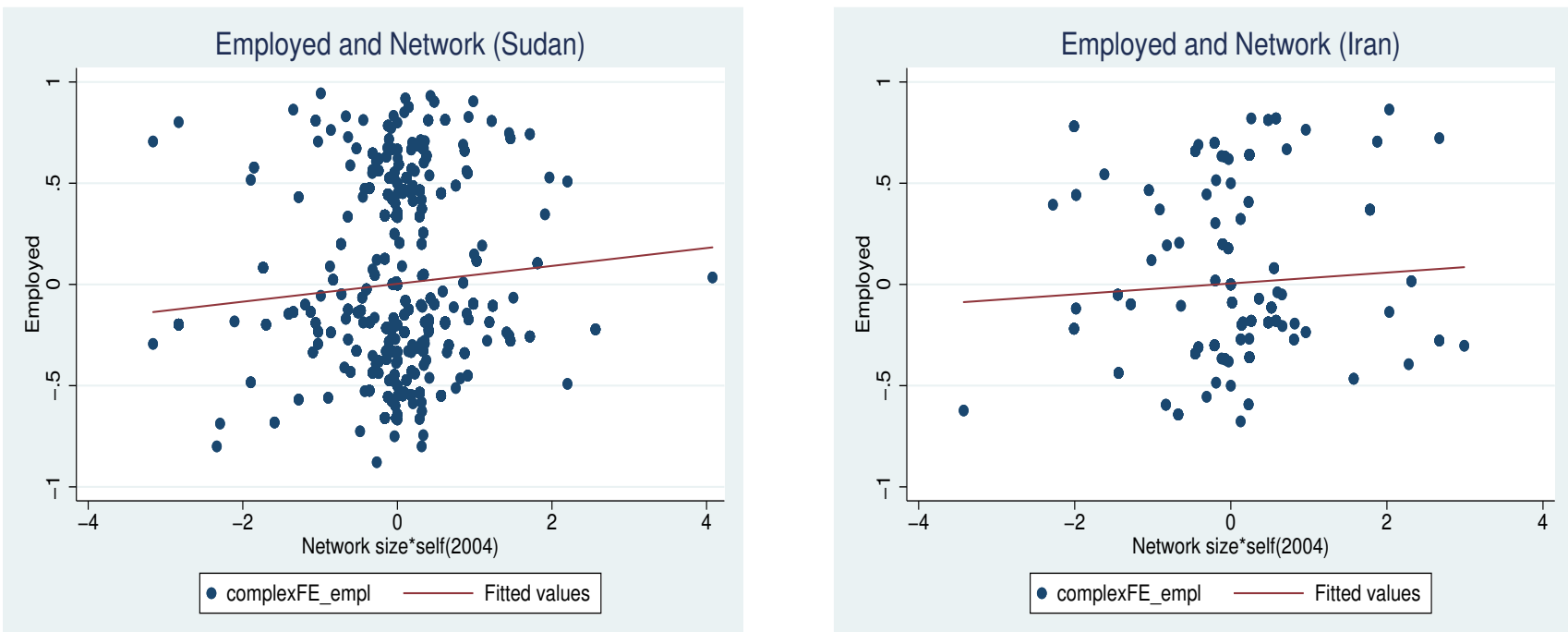

(c) Correlation between employment and network size (d) Correlation between employment and network size (Sudan) (Iran)

Note: All variables are partialled-out by commuting zone-year, nationality-year, and commuting-nationality fixed effects. 
Figure B.3. Migrants vs. Refugees (without U.S. ties), in 2005-2010

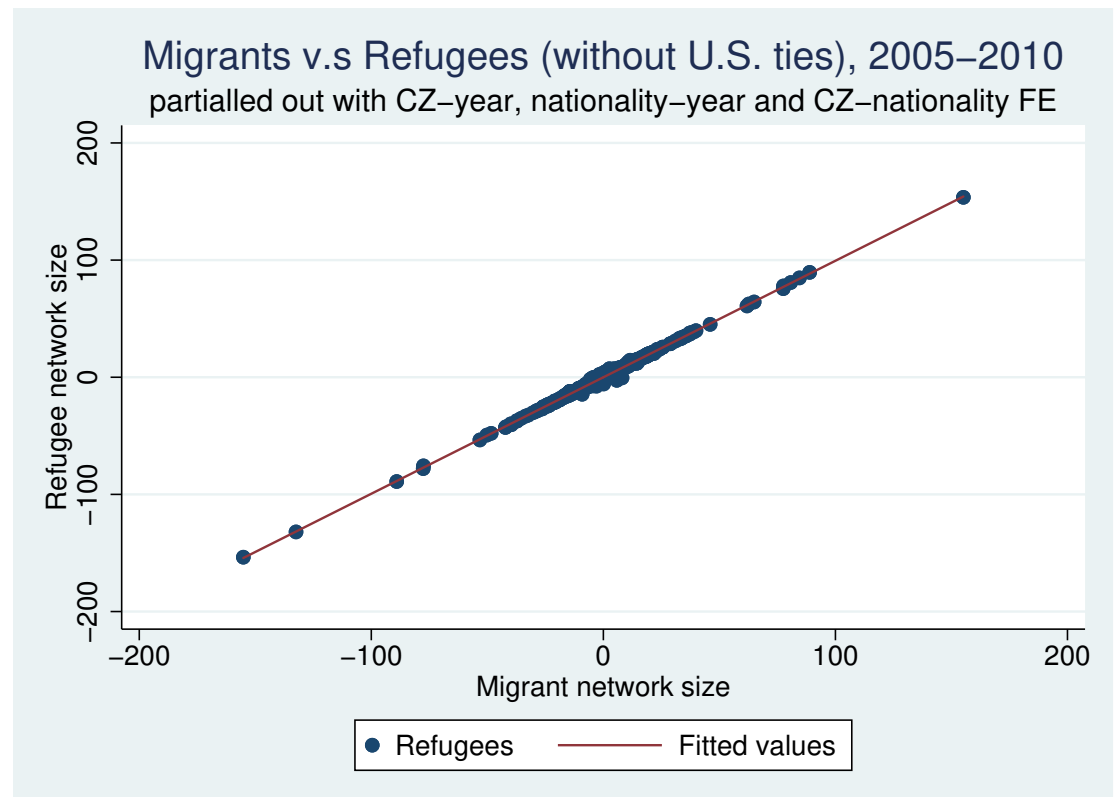

Note: Networks are constructed by summing the refugees arrivals up the previous year between 2005 and 2010.All variables are partialled-out by commuting zone-year, nationality-year, and commuting-nationality fixed effects. Source: WRAPS and American Community Survey. 


\section{Appendix C Description of alternative networks}

We produced alternative networks for refugees of nationality $i$ based on the bilateral linguistic / religious proximity between country $i$ and all the other $j$ nationalities present at the commuting zone (CZ) level. We used Melitz and Toubal's dataset (2014) on linguistic proximity to compute, for each year, an alternative network for each refugee nationality present at the commuting level.

$$
\text { Linguistic Network }_{i t}=\sum_{j \neq i} \text { Refugee Number }_{j t} * \text { Linguistic Proximity }_{i j}
$$

with $i$, the nationality of the refugees of interest, $j$, the other refugee nationalities present in the same $\mathrm{CZ}$ and $t$, the year. ${ }^{27}$ These alternative networks come in addition to the networks of refugees from nationality $i$.

For each nationality $i$, we compute the predicted number of entrepreneurs of different nationalities based on linguistic or religious proximity, as follows:

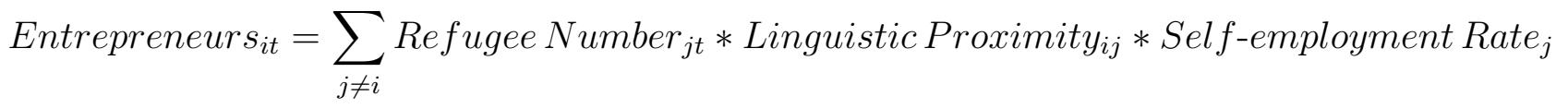

In the case of the predicted number of employees of different nationalities for refugees of nationality $i$, we use the employment rate of the $j$ nationalities present in the commuting zone.

Networks based on religion are computed similarly using the bilateral religious proximity instead of linguistic proximity.

The bilateral dataset on religious proximity was built thanks to data on religious composition by country in 2010 taken from The Global Religious Landscape, a Pew Research Center publication. Bilateral religious proximity is the probability that one random citizen from country $i$ is of the same religion as one random citizen from country $j$. It is computed as follows

$$
\text { Religious Proximity }_{i j}=\sum_{r=1}^{6} \text { Population Percentage }_{r i} * \text { Population Percentage }_{r j}
$$

with Population Percentage ri $_{i}$ being the percentage of citizens of religion $r$ from country $i$ (same for country $j$ ). The six religions considered are Christianity, Islam, Hinduism, Buddhism, Judaism and Folk or Traditional religions.

\footnotetext{
${ }^{27}$ Note that since we lacked information on the bilateral linguistic proximities between Burma and Djibouti and Korea, we took the average of the linguistic proximities of their neighboring countries. For Djibouti: Eritrea, Ethiopia, Somalia and Yemen and for Korea, Russia, China and Japan.
} 